Transactions of the Karelian Research Centre of the Russian Academy of Sciences

No. 2. 2019. P. 5-25

DOI: $10.17076 /$ geo841
Труды Карельского научного центра РАН

№ 2. 2019. C. 5-25

УДК 552.3:551.24

\title{
NEOARCHEAN SANUKITOIDS FROM THE KARELIAN AND BUNDELKHAND CRATONS: COMPARISON OF COMPOSITION, REGIONAL DISTRIBUTION AND GEODYNAMIC SETTING
}

\author{
K. B. Joshi ${ }^{1,2}$, A. I. Slabunov ${ }^{3}$ \\ ${ }^{1}$ Physical Research Laboratory, Ahmedabad, Gujrat, India \\ ${ }^{2}$ ESSO-National Centre for Earth Science Studies, Thiruvananthapuram, Kerala, India \\ ${ }^{3}$ Institute of Geology, Karelian Research Centre, Russian Academy of Sciences, \\ Petrozavodsk, Karelia, Russia
}

\begin{abstract}
This study presents the comparative distribution and composition of Neoarchean sanukitoid massifs from the Karelian (Fennoscandian Shield) and Bundelkhand (Indian Shield) Cratons. It has been established that sanukitoid massifs from both the cratons are localised in linear zones nearly parallel to their respective greenstone belts. Neoarchean $(2.56-2.53 \mathrm{Ga})$ sanukitoids from Bundelkhand are geochemically similar to those from Central and Western Karelian zones $(2.72-2.68 \mathrm{Ga})$ while they are less differentiated as compared to the sanukitoids from Eastern Karelia (2.74-2.73 Ga). The geochemical similarities in sanukitoids from both these cratons, their proximity with coeval arctype volcanic rocks and location in linear zones are suggestive that subduction related processes might have been responsible for their formation in both Karelian as well as Bundelkhand cratons.
\end{abstract}

Ke y w o r d s: Sanukitoids; Karelian Craton; Bundelkhand Craton; Archean; Geodynamics.

\section{К. Б. ДЖОШИ, А. И. СЛабУНОВ. НЕОАРХЕЙСКИЕ САНУКИТОИДЫ КА- РЕЛЬСКОГО И БУНДЕЛКХАНДСКОГО КРАТОНОВ: СРАВНЕНИЕ ПО СО- СТАВУ, ПРОСТРАНСТВЕННОМУ РАСПРЕДЕЛЕНИЮ И ГЕОДИНАМИ- ЧЕСКОЙ ОБСТАНОВКЕ}

В данной работе проводится сопоставление распределения в пространстве и состава неоархейских санукитоидных массивов Карельского (Фенноскандинавский щит) и Бунделкхандского (Индийский щит) кратонов. Показано, что в обоих рассматриваемых кратонах массивы санукитоидов локализуются в линейных зонах, близких по ориентировке зеленокаменным поясам. Неоархейские (2,56-2,53 млрд лет) санукитоиды Бунделкхандского кратона по петрохимическим особенностям сходны с аналогичными породами Центрально- и Западно-Карельской зон Карельского кратона с возрастом 2,72-2,68 млрд лет, вместе с тем они менее дифференцированы по сравнению с санукитоидами Восточно-Карельской зоны (2,74-2,73 млрд лет). Санукитоиды обоих рассматриваемых кратонов сходны по геохимическим характеристикам и сопоставимы с субдукционными комплексами, кроме того, с ними ассоциируют близкие по возрасту островодужные вулканиты. Все это, наряду с линейным характером распределения в пространстве, позволяет рассматривать их как субдукционные образования. 
Ключе в ы е с л о ва: санукитоиды; Карельский кратон; Бунделкхандский кратон; архей; геодинамика.

\section{Introduction}

Sanukitoids (High Mg, Ba, Sr diorites-granodiorites-monzogranites) are typical Archean rocks as are komatiites, tonalite-tondhjemite-granodiorites (TTGs), and Banded Iron Formations (BIFs). Despite the fact that the Archean represents the dominant period of crustal growth, its preservation and the geodynamic framework is controversial and straddles between plate tectonic [De Wit, 1998; Condie and Benn, 2006; Shchipansky, 2012; Hölttä et al., 2014] and non-plate tectonic models [Hamilton, 1998, 2011; Harris and Bédard, 2014]. Higher mantle temperature and compositionally different atmosphere during the Archean resulted in the formation of typical Archean lithologies like sodium rich TTG suite, komatiites, BIFs, the late high- $\mathrm{K}$ granitoids and the rocks of sanukitoid series [Brown, 1985, 2007; Sylvester, 1994; Reddy and Evans, 2009; Herzberg et al., 2010; Martin et al., 2010; and references therein]. Additionally, arc-type basalt, andesite, dacite and ryolite (BADR), adakites, boninitic series rocks [Polat and Kerrich, 2002; Malviya et al., 2006; Svetov, 2009] are common lithologies in Archean cratons. There have been reports of Archean eclogites and eclogitic facies rocks in both Fennoscandian and Indian shields [Volodichev et al., 2004; Mints et al., 2010; Saha et al., 2011; Li et al., 2015].

TTGs are the major component of the Archean crust. They are sodic, rich in silica often have high $\mathrm{La}_{\mathrm{N}} / \mathrm{Yb}_{\mathrm{N}}$ abundances and moderate to high $\mathrm{Sr} / \mathrm{Y}$ at low $\mathrm{Y}$ abundances [Hoffmann et al., 2011; Condie, 2014]. The origin of these rocks has been widely debated with models ranging from subducting hydrous basaltic slab [Arth and Hanson, 1972; Martin and Moyen, 2002 and references therein; Foley et al., 2002; Laurie and Stevens, 2012] to an over thickened mafic crust [Hoffman et al., 2011] as a source in plume related plateau basalt [Condie, 2005, 2014; Foley, 2008; Smithies et al., 2009; Willbold et al., 2009] or within tectonically thickened island arc crust [Adam et al., 2012; Nagel et al., 2012; Hoffmann et al., 2014], while some propose a role of intracrustal differentiation which later evolved by crystal fractionation of primitive andesitic melt [Kelemen et al., 2014]. However, the most widely accepted mechanism for the origin of TTG magmas is by partial melting of hydrous metabasaltic rocks [Rapp et al., 1991; Patiño Douce and Beard, 1995; Rapp and Watson, 1995].
In addition to the abundant TTG suites, K-rich granitoids (sanukitoids and granite-granodioritemonzogranite (GGM) series) are prominent (Fig. 1) in many Neoarchean cratons [Sylvester, 1994; Egorova, 2014]. The several generations of these $\mathrm{K}$-rich granites have been attributed to partial melting of a lower crust [Champion and Sheraton, 1997; Mikkola et al., 2012 and references therein] and mantle derived source contaminated by continental crust as in the case of sanukitoid suite of rocks [Shirey and Hanson, 1984; Stern et al., 1989; Smithies and Champion, 2000; Halla, 2005; Heilimo et al., 2011; Feio and Dall'Agnol, 2012; Joshi et al., 2017]. Sanukitoids, first identified by Shirey and Hanson [1984], have been reported from Neoarchean terranes all around the world (Fig. 1). Sanukitoids have geochemical characteristics typical of both Archean TTGs and modern BADR series [Laurent et al., 2011] and are considered to have formed up to the Neoarchean. However, Phanerozoic analogues of Neoarchean sanukitoids have been reported from Caledonian Scotland [Fowler and Rollinson, 2012]. Recently, granitoids with sanukitoid affinities but lacking typical sanukitoid features have been reported. The most notable granitoid with such character is the Closepet granitoid in the Dharwar Craton, India [Jayananda et al., 1995; Moyen et al., 2001]. However, similar compositions have also been reported from Wyoming [Frost et al., 1998], Shandong (China) [Jahn et al., 1988], Limpopo [Barton et al., 1992], Aravalli and Bundelkhand Cratons (India) [Mondal and Raza, 2013; Joshi, 2014; Joshi et al., 2017]. Martin et al. [2005] considered that similar petrogenitic processes were responsible for the formation of Closepet granite and sanukitoids. Therefore, both these suites will be considered as part of sanukitoids in the following text.

Sanukitoids range from high-Mg diorites, monzodiorites to granodiorites and are often associated with syenites, lamprophyres, and coeval mafic enclaves which were emplaced between 2.9 and $2.5 \mathrm{Ga}$ [Laurent et al., 2011; Fowler and Rollinson, 2012]. Sanukitoids can compositionally range from mafic to felsic end members with typical silica concentration ranging from 50 to $75 \mathrm{wt}$. \% and $\mathrm{MgO}$ contents of $\sim 0.1$ to $8 \mathrm{wt}$ \% [Martin et al., 2010]. A distinct feature that separates sanukitoids from TTGs is the relatively high content of both compatible (e. g. Mg, Ni, Cr) and incompatible elements of sanukitoids at a given silica content [Heilimo et al., 2011]. The petrogenesis of sanukitoids is still 


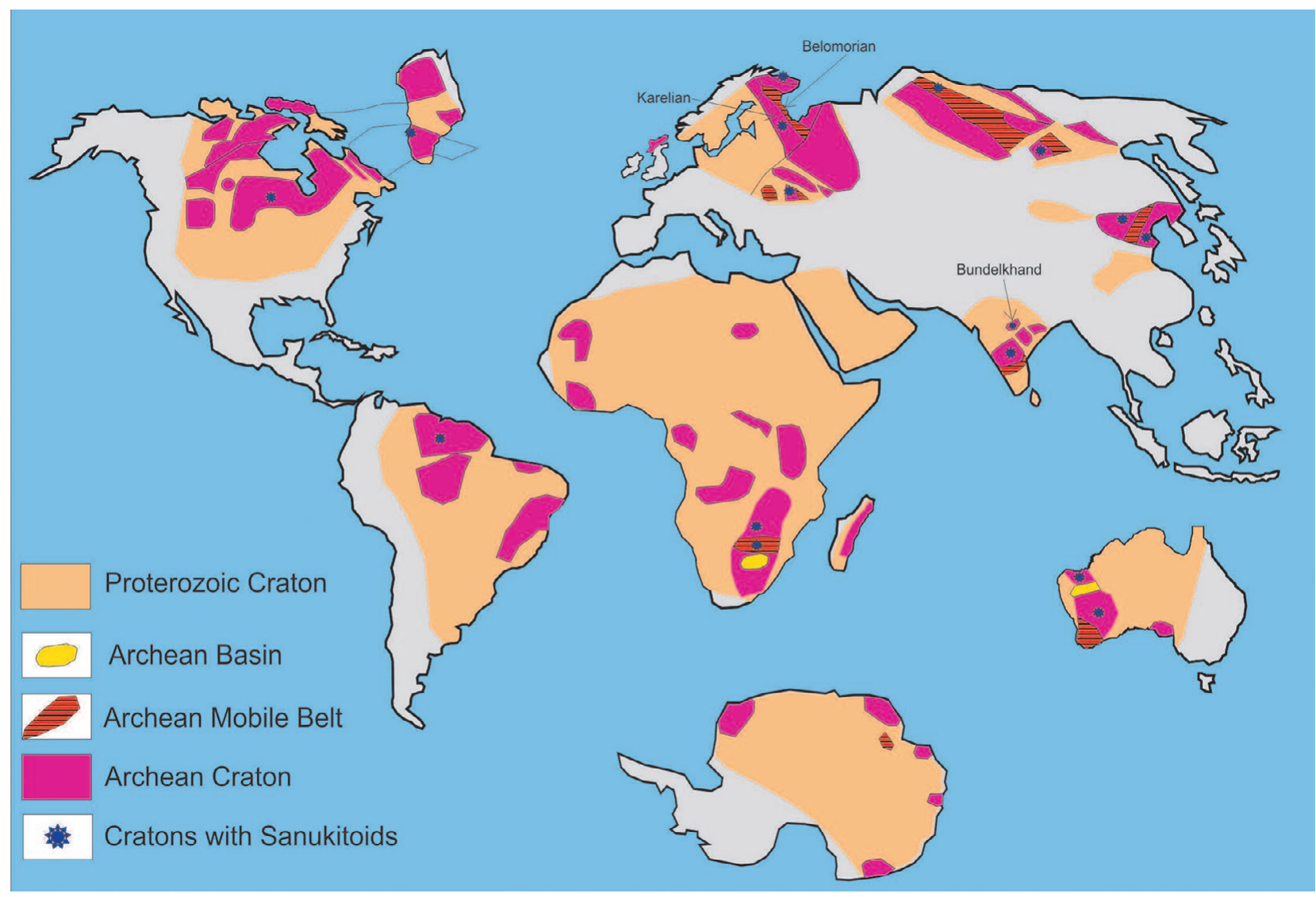

Fig. 1. Global distribution of main Archean structures [modified after: Bleeker, 2003; Slabunov, 2008] and sanukitoids (data in text)

a topic of discussion. Some believe their derivation by direct melting of an enriched mantle source [Stern, 1989; Stern and Hanson, 1991; Stevenson et al., 1999] while others believe in variable extents of interactions between mantle peridotite and TTG magmas in subduction environments [Jayananda et al., 1995; Smithies and Champion, 1999, 2000; Martin et al., 2005; Moyen, 2011]. The agent of enrichment might range from slab derived adakite melt [Martin et al., 2010] to subducted terriginous sediments [Laurent et al., 2011]. Mikkola et al. [2011] suggested that the Neoarchaean appearance of several distinct mantle derived suites, i. e., sanukitoid series of rocks displaying compositional similarities as well as differences, can be explained with a two phase metasomatism model [Halla et al., 2009; Heilimo et al., 2010] wherein the mantle source is metasomatized first during subduction by fluids and melts from the subducting slab and / or sediments and later by upwelling alkaline fluids, following slab breakoff, which, based on numerical modeling [van Hunen and van den Berg, 2008], were more frequent in the hotter Archean mantle. However, some researchers even suggest mantle plume as a probable cause for melting of metasomatised mantle [Kovalenko et al., 2005;
Egorova, 2014; Mints et al., 2015] and formation of sanukitoids.

The distribution of sanukitoids in space and time is crucial to understand the geodynamic setting in which they formed. In this study, we 1) compare the petrology, geochemistry and distribution of Neoarchean sanukitoids from the Karelian (Fennoscandian Shield) and Bundelkhand (Indian Shield) Cratons; 2) try to establish a time-space relationship between sanukitoid massifs and volcanogenic complexes; and further 3 ) synthesize the data obtained to understand the geodynamic processes that were operative for the formation of sanukitoids.

\section{Geological setting}

\section{Karelian Craton}

The Karelian Craton (Fig. 2) is the oldest core of the Fennoscandian Shield. It is subdivided into five blocks (or Provinces) viz. Norrbotten, Murmansk, Kola, Belomorian and Karelian [Slabunov et al., 2006a, b; Hölttä et al., 2008, 2012, 2014]. The Karelian and Murmansk blocks form the cratonic nuclei and therefore, have been referred 


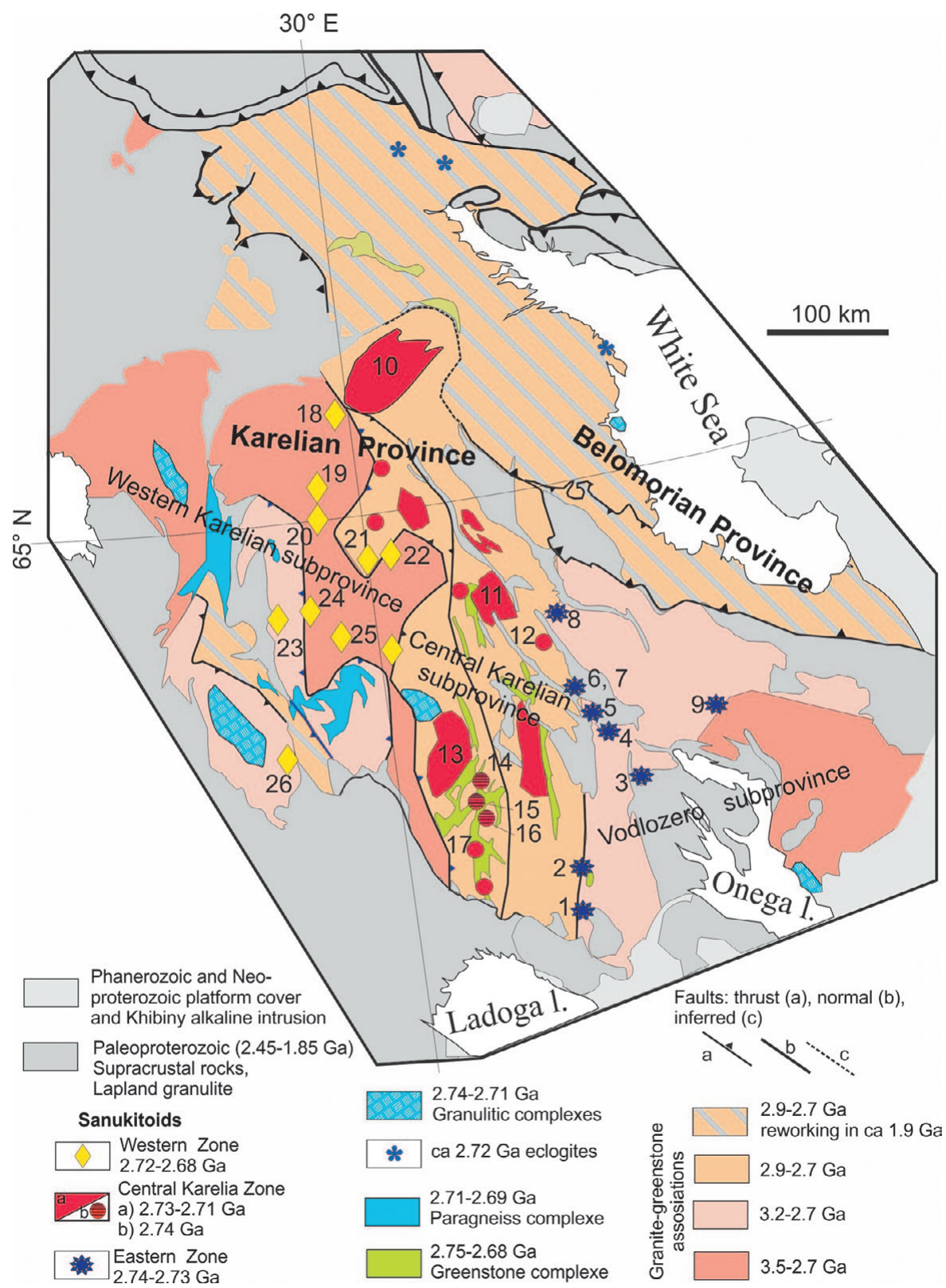

Fig. 2. A generalised geological map of the Archean of the Karelian and Belomorian Provinces, Fennoscandian shield [modified after: Slabunov et al., 2006a, b, 2011a; Hölttä et al., 2008, 2014; Kulikov et al., 2017] and distribution of sanukitoids (more data in text and table 1)

to as the Karelian and Murmansk Cratons [Slabunov et al., 2006a, b] while the Belomorian Province is a mobile belt, which is a superposition of Archean (2.9-2.7 Ga) and Paleoproterozoic (2.0-1.9 Ga) orogens [Daly et al., 2006; Balagansky et al., 2015]. Sanukitoid massifs are common in the Karelian Craton, there are a few reported in the Murmansk Craton and Kola Belt, but absent in the Belomorian Belt [Slabunov, 2008; Egorova, 2014]. The Norrbotten Craton has not been studied in detail but there are no reports of sanukitoids in that area [Lauri et al., 2016].
The Karelian Craton has been divided into three subprovinces i. e. Vodlozero, Central Karelia and Western Karelia based on lithology, structural and age relations [Lobach-Zhuchenko et al., 2005; Hölttä et al., 2012]. In general, the Vodlozero and Western Karelia sub-provinces include Neoto Paleoarchean TTGs and greenstone complexes while the Central Karelia sub-province is generally Neoarchean and consists of recycled Mesoarchean crustal material [Slabunov et al., 2006a, b; Hölttä et al., 2012, 2014, 2017; Käpyaho et al., 2017]. 
The Vodlozero sub-province is in the south-eastern part of the Karelian Province and consists of TTGs (3.24-2.8 Ga) and greenstone (3.05-2.74 Ga) complexes which are cut by $2.98 \mathrm{Ga}, 2.4 \mathrm{Ga}, 2.0 \mathrm{Ga}$ mafic intrusions, and Neoarchean granitoids [Chekulaev et al., 2009; Svetov et al., 2010; Hölttä et al., 2012, 2014, 2017, 2019]. The 2.75-2.73 Ga sanukitiod massifs (Fig. 2, Table 1) are common in the western part of this sub-province [Bibikova et al., 2004; Egorova, 2014; Kulikov et al., 2017]. Three age groups of greenstone complexes have been reported in Vodlozero: 1) 3.05-2.97 Ga basalt-komatiite and basalt-andesite-dacite-rhyolite suites; 2) 2.86-2.8 Ga - a) basalt-komatiite and adakite suites, b) rift-type quartz arenites with komatiite; 3) 2.76-2.74 Ga - felsic volcanic rocks [for review see Slabunov et al., 2006a, b; Svetov et al., 2010 and Hölttä et al., 2012, 2014]. These complexes form the Vedlozero-Segozero, South Vygozero and Sumozero-Kenozero greenstone belts. Meso- $(3.1 \mathrm{Ga})$ and Neoarchean (2.7-2.74 Ga) low-pressure granulitic complexes have also been reported in this terrane [Slabunov et al., 2006a, b, 2013] along with felsic volcanic rocks $(2.74 \mathrm{Ga})$ that have ages similar to those of the sanukitoids.

The Western Karelian sub-province is divided into the Ranua, lisalmi, Ilomantsi, Rautavaara and Kianta terranes [Sorjonen-Ward and Luukkonen, 2005; Slabunov et al., 2006a, b]. Siurua gneisses $(\sim 3.5 \mathrm{Ga})$ located in the Ranua complex are the oldest dated rocks in the Karelian Province [Mutanen and Huhma, 2003]. The Western Karelian sub-province consists of Meso-Neoarchean TTG, granitoids, greenstones and paragneisses complexes. Two age groups of greenstone complexes have been reported in the province 1) ca $2.94 \mathrm{Ga}-$ adakite-type felsic volcanogenic rocks (Luoma Group) and 2) 2.84-2.79 Ga - basalts-komatiites, Fe-basalts, felsic volcanite, BIF and sediments [Sorjonen-Ward and Luukkonen, 2005; Slabunov et al., 2006a, b; Huhma et al., 2012; Hölttä et al., 2012, 2014; Lehtonen et al., 2016]. These complexes formed the Tipasjarvi, Kuhmo, Suomussalmi, Kostomuksha, Oijärvi and Kovero greenstone belts. The youngest supracrustal Archean rocks in this sub-province are Neoarchean (2.71-2.69 Ga) Nurmes paragneisses with minor metabasalts (amphibolite) [Kontinen et al., 2007]. Local TTGs, sanukitoids and mafic rocks have been suggested as a probable source for these wackes, which formed in a back-arc or intra-arc basin [Kontinen et al., 2007]. Neoarchean medium-pressure granulites complexes have also been reported in lisalmi terrane [Hölttä et al., 2000]. Sanukitoids (Fig. 1) with age 2.73-2.72 (up to 2.69) Ga (Table 1) are common in the Western Karelia sub-province, together with slightly younger $(\sim 2.70 \mathrm{Ga})$ granitoid groups like enderbites, quartz diorites, syenites and GGM suite [Käpyaho et al., 2006; Mikkola et al., 2013, 2017 and references therein; Hölttä et al., 2014]. Recently, new Neoarchean (ca $2.71 \mathrm{Ga}$ ) complexes of alkali-enriched gabbro and diorite were reported in the Western Karelia sub-province [Mikkola et al., 2017]. This complex formed the last collisional stage in a Himalayan-Tibetian style tectonic setting [Slabunov et al., 2016; Mikkola et al., 2017].

The Central Karelian sub-province is in the central part of the craton (Fig. 2) and mainly has younger $(<2.80 \mathrm{Ga}$ with a few occurances of $2.90 \mathrm{Ga})$ crust [Lobach-Zhuchenko et al., 2000; Slabunov et al., 2006a, b; Huhma et al., 2012; Hölttä et al., 2012, 2014]. Despite TTGs being the dominant lithology in this subprovince, the biggest Neoarchean sanukitoid intrusions are also located here (Fig. 2). Two generations of sanukitoids have been reported in the Central Karelian sub-province 1) 2.75-2.74 Ga and 2) $2.72-2.70 \mathrm{Ga}$ [SorjonenWard and Claoue-Long, 1993; Heilimo et al., 2011]. The greenstone complexes of this province (Ilomantsi and Gimoli-Bol'shozero greenstone belts) essentially consist of volcaniclastic graywackes with felsic and mafic volcanic rocks, BIFs and komatiites which were formed at $\sim 2.75-2.73 \mathrm{Ga}$ with intensive hydrothermal events at $2.73-2.71 \mathrm{Ga}$ [Sorjonen-Ward and Claoue-Long, 1993; Slabunov et al., 2006a, b; Hölttä et al., 2014; Käpyaho et al., 2017]. Neoarchean low-pressure granulitic complexes (Tulos and Voknavolok) have recently been reported in this sub-province [Slabunov et al., 2006a, b, 2015; Heilimo et al., 2010; Mikkola et al., 2013; Hölttä et al., 2017].

\section{Bundelkhand Craton}

The Central Indian Tectonic Zone (CITZ) divides the Indian shield into two Archean blocks; Northern and Southern. Aravalli and Bundelkhand cratons form part of the northern block while Singhbhum, Bastar and Dharwar cratons form part of the southern block [Acharya, 2003]. The Bundelkhand Craton is situated to the north of the CITZ and covers an area of $26,000 \mathrm{~km}^{2}$. The craton (Fig. 3) is overlain by Indo-Gangetic alluvium to the north, Paleoproterozoic Gwalior and Bijawar basin to the north, south, and southeast and Mesoproterozoic Vindhayan Supergroup to the southeast, southwest and west [Basu, 1986; Sarkar et al., 1996; Ramakrishnan and Vaidyanadhan, 2010]. The Bundelkhand Craton consists of the Archean (TTG-gneisses, greenstone, metasedimentary and mafic-ultramafic complexes [Slabunov et al., 2018a, b], surrounded by Neoarchean Bundelkhand granitoids [Singh et al., 2018], which are cut across by Paleoproterozoic quartz reefs 
Table 1. The ages (in Ma) of sanukitoids from the Karelian and Bundelkhand Cratons

\begin{tabular}{|c|c|c|c|c|c|}
\hline Intrusion & Rock Name & Age (Ma) & U-Pb method & References* $^{*}$ & No on map \\
\hline \multicolumn{6}{|c|}{ KARELIAN CRATON } \\
\hline \multicolumn{6}{|c|}{ 1) Eastern Sanukitoid Zone } \\
\hline Hautavaara & Monzodiorite, granite & $2743 \pm 8,2742 \pm 23$ & SIMS & 2 & 1 \\
\hline Chalka & Granodiorite & $2745 \pm 5$ & ID-TIMS & 15 & 2 \\
\hline Elmus & Quartz monzonite & $2742 \pm 8$ & SIMS & 2 & 3 \\
\hline Bergaul & Monzogranite & $2730 \pm 17$ & ID-TIMS & & 4 \\
\hline \multirow[t]{3}{*}{ Panozero } & $\begin{array}{l}1^{\text {st }} \text { Phase: Mafic-ultramafic, } \\
\text { monozite, lamproite, } \\
\text { lamprophyre }\end{array}$ & $\begin{array}{l}(2765 \pm 8 \\
2785 \pm 38) \\
2740 \pm 14 \\
2744 \pm 18 \\
2737 \pm 11\end{array}$ & SIMS & $2,6,17$ & 5 \\
\hline & $\begin{array}{l}2^{\text {nd }} \text { Phase: diorites, quartz } \\
\text { monozite }\end{array}$ & $\begin{array}{l}2739 \pm 11 \\
2727 \pm 4\end{array}$ & \begin{tabular}{|l|} 
SIMS \\
ID-TIMS
\end{tabular} & 2,4 & \\
\hline & $\begin{array}{l}3^{\text {rd }} \text { Phase: granodiorite, quartz } \\
\text { monozite }\end{array}$ & $\begin{array}{l}2741 \pm 8 \\
2736 \pm 14 \\
2734 \pm 17\end{array}$ & \begin{tabular}{|l|} 
SIMS \\
ID-TIMS
\end{tabular} & 2,4 & \\
\hline Sjargozero & $\begin{array}{l}\text { Lamprophyre, granodiorite, } \\
\text { syenite }\end{array}$ & $\begin{array}{l}2742 \pm 16 \\
2738 \pm 12 \\
2735 \pm 14 \\
2734 \pm 15\end{array}$ & \begin{tabular}{|l|} 
SIMS \\
ID-TIMS
\end{tabular} & 2,3 & 6 \\
\hline Sharavalampi & Pyroxenite, gabbro, diorite & 2726 (Tit) & ID-TIMS & 5 & 7 \\
\hline Khizhjarvi & Syenite, pyroxenite & \begin{tabular}{|l|}
$2748 \pm 13$ \\
$2744.5 \pm 4$ \\
$2739.9 \pm 4.1$ \\
\end{tabular} & \begin{tabular}{|l|} 
SIMS \\
ID-TIMS
\end{tabular} & 3 & 8 \\
\hline Konzhozero & Syenite, monzogranite & $2762 \pm 9 ; 2743 \pm 15$ & SIMS & 19 & 9 \\
\hline \multicolumn{6}{|l|}{ 2) Central Karelia } \\
\hline Pjozero & Gabbro, diorite, granodiorite & \begin{tabular}{|l|}
$2724.4 \pm 7.8$ \\
$2725(\mathrm{Sm}-\mathrm{Nd})$ \\
\end{tabular} & ID-TIMS & 1,14 & 10 \\
\hline Njuk-Bolshozero & Granodiorite, diorite & $\begin{array}{l}2709 \pm 10 \\
2716 \pm 11 \\
2705 \pm 5 \\
2732 \pm 4\end{array}$ & \begin{tabular}{|l} 
SIMS \\
ID-TIMS
\end{tabular} & 2 & 11 \\
\hline Amindomoj & Gabbro, diorite & $2725 \pm 20$ & ID-TIMS & 11 & 12 \\
\hline Koitere & Granodiorite & $2722 \pm 6$ & SIMS & 9 & 13 \\
\hline Tasanvaara & Tonalite & $2748 \pm 6$ & ID-TIMS & 18 & 14 \\
\hline Kuittila & Tonalite & $2741 \pm 9$ & SIMS & 9 & 15 \\
\hline Sysmajarvi & Tonalite/quartz diorite & $2744 \pm 5$ & SIMS & 9 & 16 \\
\hline Ilomantsinjärvi & Granodiorite & $2728 \pm 7$ & SIMS & 9 & 17 \\
\hline \multicolumn{6}{|c|}{ 3) Western Sanukitoid Zone } \\
\hline Kuusamo & Granodiorite & $2718 \pm 5$ & SIMS & 9 & 18 \\
\hline Kaapinsalmi & Tonalite & $2722 \pm 4$ & SIMS & 9,8 & 19 \\
\hline Raate & Granodiorite & $2713 \pm 3$ & ID-TIMS & 10 & 20 \\
\hline Kaartojärvet & Gabbro & $2715 \pm 3$ & SIMS & 13 & 21 \\
\hline $\begin{array}{l}\text { Kurgelampi } \\
\text { (Taloveis) }\end{array}$ & Diorite, Granodiorite & \begin{tabular}{|l|}
$2725 \pm 16 ;$ \\
$2715 \pm 5 ; 2710 \pm 27$ \\
\end{tabular} & SIMS & 2,16 & 22 \\
\hline Loso & Diorite & $2719 \pm 19$ & SIMS & 13 & 23 \\
\hline Arola & Granodiorite & $2723 \pm 6$ & SIMS & 9 & 24 \\
\hline Siikalahti & Granodiorite & $2683 \pm 9$ & SIMS & 13 & 25 \\
\hline Nilsiä & Granodiorite & $2724 \pm 28$ & SIMS & 7,9 & 26 \\
\hline \multicolumn{6}{|c|}{ BUNDELKHAND CRATON } \\
\hline Karera & Granodiorite to granite & $2563 \pm 2 ; 2559 \pm 7$ & SIMS & 12 & \\
\hline Orccha & Granodiorite to granite & $2560 \pm 7$ & SIMS & 12 & \\
\hline Khajuraho & Monzogranite & $2544 \pm 6$ & SIMS & 12 & \\
\hline
\end{tabular}

Note. ${ }^{*} 1$ - Bibikova et al., 1997; 2 - Bibikova et al., 2005; 3 - Bibikova et al., 2006; 4 - Chekulaev et al., $2003 ; 5$ - Dmitrieva Kuleshevich, 2018; 6 - Guseva et al., 2009; 7 - Halla, 2005; 8 - Heilimo et al., 2007; 9 - Heilimo et al., 2011; 10 - Heilimo et al., 2013; 11 - Ivanikov, 1997; 12 - Joshi et al., 2017, 13 - Käpyaho et al., 2006; 14 - Larionova et al., 2007; 15 - Ovchinnikova et al., $1994 ; 16$ Samsonov et al., 2004; 17 - Sergeyev et al., 2007; 18 - Vaasjoki et al., 1993; 19 - Zhitnikova et al., 2012. 


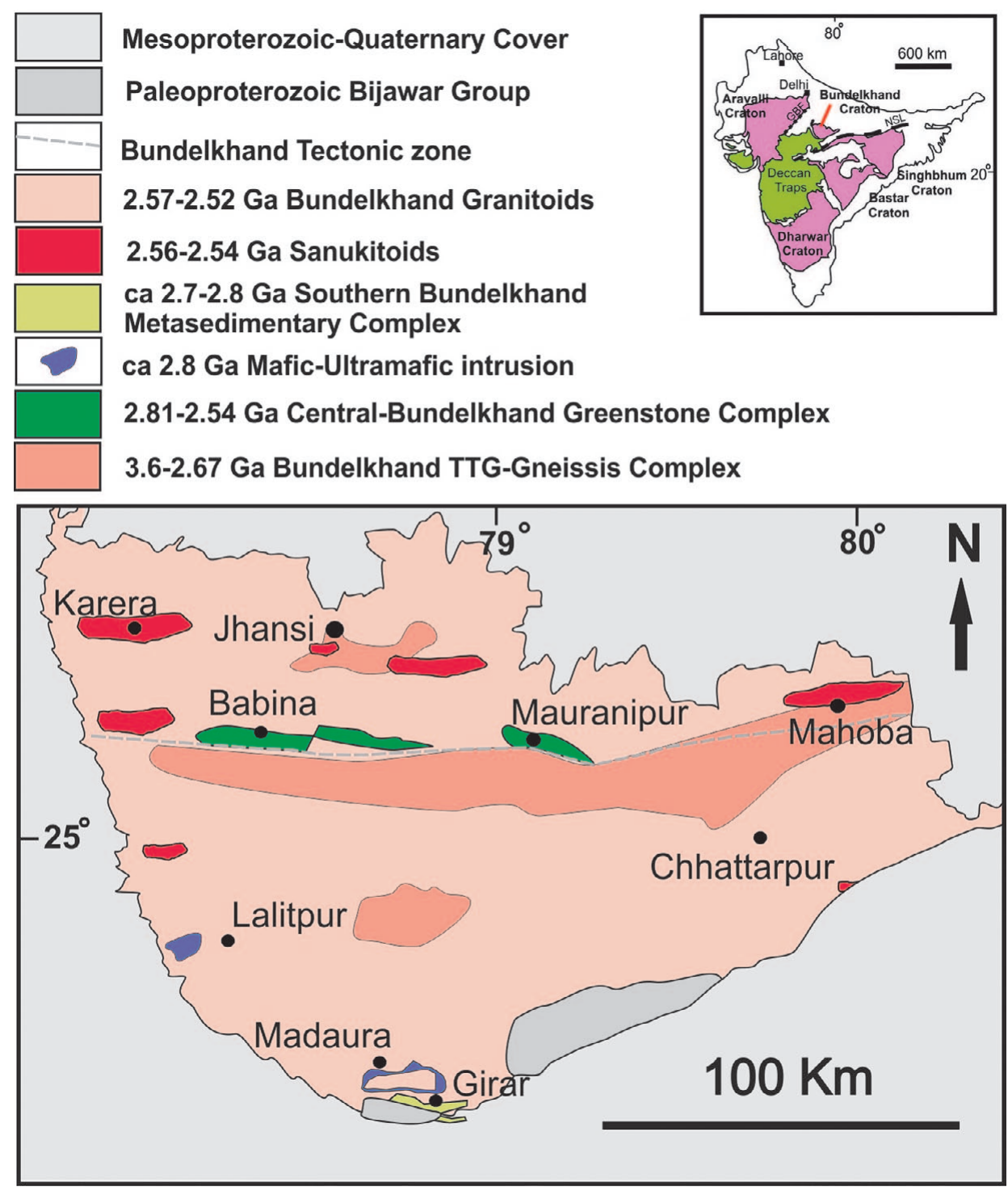

Fig. 3. Generalized geological map of the Bundelkhand Craton [modified after: Basu, 1986; Singh, Slabunov, 2016; Joshi et al., 2017; Slabunov, Singh, 2018b]. The inset shows an outline map of India with the different cratons of the Indian Shield [modified after: Radhakrishna, 1989]

[Pati et al., 2007; Slabunov et al., 2017b] and mafic dyke swarms [Sharma and Rahman, 2000]. The gneissic complex encompasses highly deformed TTGs of variable ages from Palaeoarchaean to Neoarchaean, while the high-K calc-alkaline granitoids are mostly late Neoarchaean.

The gneissic complex is easily distinguishable from the granitoids based on deformation and intrusive relationship, and forms the basement along which low-grade (greenschist to lower amphibolite facies) metasedimentary and metavolcanic rocks are exposed. Joshi et al. [2017] divided TTGs from the craton on the basis of geochemistry into low HREE and enriched TTGs which were formed by low-degree partial melting of basalt or amphibolite while in situ melting of amphibolite enclaves formed the enriched varieties. The oldest ages from TTGs $(\sim 3.5 \mathrm{Ga})$ are reported from Mauranipur and Babina areas from the central part of the craton [Sarkar et al., 1996; Kaur et al., 2014; Saha et al., 2016]. Ages as old as $3.3 \mathrm{Ga}$ have been reported from the eastern part (Mahoba) of the craton [Mondal et al., 2002; Joshi et al., 2017] while Verma et al. [2016] reported an age of $2.66 \mathrm{Ga}$ from a trondhjemite sample in Babina.

The Bundelkhand metasedimentary and metavolcanic rocks (greenstone complexes) [Singh and Bhattacharya, 2010; Singh, 2012] are mainly exposed along two east - west-trending lineaments in the central and southern parts of the Craton [Singh and Slabunov, 2013, 2015, 2016; Slabunov and Singh, 2018b] (Fig. 3). The Central- 
Bundelkhand Greenstone belt consists of a metamorphosed tholeiitic basalt and high Mg-basalt association, two age (2.81 and $2.54 \mathrm{Ga})$ groups of felsic volcanics and banded iron formation (BIF) while the Southern Bundelkhand greenstone (schist) complex consists of basic quartzites, BIF and lenses of dolomitic marble and chlorite schist near the quartzite/BIF boundary [Malviya et al., 2006; Singh and Slabunov, 2015, 2016; Slabunov et al., 2017a]. Singh and Slabunov [2015], Slabunov and Singh [2018b] dated porphyritic dacites from Babina and Mauranipur and metadacite from Mauranipur and reported zircon ages of 2.54-2.56 Ga and $2.81 \mathrm{Ga}$, respectively. The U-Pb age of a detrital zircon grain from the BIF of the Southern Bundelkhand greenstone (schist) complex from Girar is estimated at $2898 \pm 26 \mathrm{Ma}$, and the age of metamorphic varieties at ca 2.7 and $2.4 \mathrm{Ga}$ [Slabunov, Singh, 2018c]. Quartzites with interbeds of fuchsite-bearing (i. e. Cr-enriched) varieties that occur below BIF contain numerous igneous zircons from granitoids of Paleoarchean (3.43 and $3.25 \mathrm{Ga}$ ) age and display a similar $\mathrm{Sm}-\mathrm{Nd}$ model age [Slabunov et al., 2017a], indicating that they were formed by recycling Paleoarchean granitoids and Mesoarchean mafic-ultramafic rocks in the period 2.8-2.7 Ga.

The Bundelkhand Granitoid Complex, the dominant lithological unit of the Bundelkhand craton, constitutes about $80 \%$ of the exposed area (Fig. 3). The granitoids were emplaced into a previously deformed basement [Mondal et al., 1998, 2002; Malviya et al., 2004, 2006]. The diversity of igneous rocks includes syeno- and monzogranites, granodiorites, diorites, alkali feldspar syenites and granite porphyries [Rahman and Zainuddin, 1993; Mondal et al., 2002]. Joshi et al. [2017], on the basis of major and trace element geochemistry, suggested that the granitoid varieties were high-K calc alkaline and divided them into Sanukitoid type monzogranites, Sanukitoid type granodiorites and Closepet type granodiorites which belong to low silica high magnesium (LSHM) group and low-HREE monzogranites, low-Eu monzogranites and monzogranites which are part of high silica low magnesium (HSLM) group. Several geochronological studies have constrained the formation of the Bundelkhand Granitoid Complex between 2.55 and 2.49 Ga [Mondal et al., 2002; Verma et al., 2016; Joshi et al., 2017]. Geochemical and geochronological signatures from PaleoNeoarchean TTGs, undeformed Neoarchean granitoids and volcano-sedimentary rocks suggest emplacement in a subduction environment with subsequent slab breakoff [Mondal et al., 2002; Singh and Slabunov, 2015, 2016; Joshi et al., 2017; Slabunov and Singh, 2018], wherein fluid assisted partial melting played a major role [Joshi et al.,
2017]. It is believed that multiphase K-rich granite magmatism $(2.55-2.49 \mathrm{Ga})$ in the early crust marks the transition from subduction setting to collision and the cratonization of the Bundelkhand craton [Crawford, 1970; Mondal et al., 1998, 2002; Meert et al., 2011; Verma et al., 2016; Singh et al., 2018]. The largescale granitic magmatism in the Bundelkhand craton overlaps temporally with similar events of granite magmatism [Verma et al., 2016] and mineralization in the adjacent Bastar (2490 Ma [Stein et al., 2004]) and Dharwar cratons (2510 Ma [Jayananda et al., 2000]).

All the above lithologies in Bundelkhand are traversed by NW trending mafic dyke swarms and NNE-SSW and NE-SW trending giant quartz veins that represent the last magma related hydrothermal activity in the Craton [Basu, 1986; Pati et al., 1997, 2007, 2008]. A variety of processes including crustal movements subsequent to stabilization, shear zones within granitic rocks and a role of late stage hydrothermal processes have been suggested for their origin [Roday et al., 1995; Pati et al., 2007]. The age of emplacement of the giant quartz veins ( $\mathrm{U}-\mathrm{Pb}$ zircon) is estimated at 1866-1779 Ma [Slabunov et al., 2017b]. However, the cross-cutting relationship with one of the mafic dyke generations suggests an age older than 2.0-1.1 Ga [Crawford, 1970; Rao et al., 2005; Pati et al., 2007; Pradhan et al., 2012].

\section{Age and distribution of sanukitoids}

Archean sanukitoid intrusions have been extensively investigated over the past three decades and have been discovered worldwide, however, information on their distribution is limited. Sanukitoids are typically $\mathrm{K}$-rich, high $\mathrm{Mg}$ intrusive rocks that range from ultramafic to felsic, which were emplaced abruptly around 3.0-2.5 Ga with a peak around $2.7 \mathrm{Ga}$, marking a sharp change in the Earth's geodynamics [Kovalenko et al., 2005; Laurent et al., 2011; Halla et al., 2017]. Sanukitoids have been found to form post episodic TTG magmatism either before or at the same time as crustderived granitoids [Heilimo et al., 2011; Joshi et al., 2017]. The time gap between the youngest TTGs and sanukitoids is very short and variable in each craton, which, together with the abrupt and temporally restricted appearance of sanukitoids, indicates a sharp change (between 3.0 and $2.5 \mathrm{Ga}$ ) in Earth's geodynamics, contradicting previous hypotheses of a transitional change [Halla et al., 2017].

\section{Karelian Craton}

Sanukitoid intrusions have been reported in all sub-provinces of the Karelian Province (Fig. 2). Till 
date about $\sim 20$ sanukitoid intrusions have been reported here, a majority of which are small except for Koitere, Pjozero and Njuk sanukitoids [Bibikova et al., 1997; Heilimo et al., 2010]. Based on age, sanukitoid intrusions in the Karelian Province have been divided into the eastern and western sanukitoids zone [Lobach-Zhuchenko et al., 2005; Bibikova et al., 2005; Heilimo et al., 2011]. However, here we prefer the division into three groups, viz., Eastern, Western and Central sanukitoids.

The Eastern Sanukitoid zone is located in western part of the Vodlozero sub-province (Fig. 2). These sanukitoids are slightly older than those of the other groups with an age range of 2.76 to $2.73 \mathrm{Ga}$ and consists of Hautavaara, Chalka, Elmus, Bergaul, Panozero, Sjargozero, Sharavalampi, Khizhjarvi and Konzhozero intrusions (Table 1). Sanukitoids in the Eastern zone intrude old volcanic rocks of the greenstone complex, however, they formed simultaneously with the $2743 \pm 12 \mathrm{Ma}$ dacitic tuffs [Svetov et al., 2010] from the youngest (2.76-2.74 Ga) greenstone complex.

Some of these sanukitoid intrusions are strongly differentiated and vary from pyroxenite to monzogranite [Lobach-Zhuchenko et al., 2005] and are related with lamprophyre dykes which are also considered as part of the sanukitoids series [LobachZhuchenko et al., 2005, 2008]. Panozero sanukitoids range from ultramafic through mafic to felsic [Lobach-Zhuchenko et al., 2005], all of which are characterized by elevated $\mathrm{K}_{2} \mathrm{O}$ contents. Ivanikov [1997] related the Panozero intrusion (2.74 Ga) to the Elmus, Sharavalampi sanukitoids and Sjargozero and Khizhjarvi syenites, all of which are of the same age and were generated in a single stage [Bibikova et al., 2005, 2006]. The Chalka sanukitoids (2.74 Ga) consist of granodiorites that cross-cut the Vedlozero-Segozero greenstone belt [Ovchinnikova et al., 1994; Bibikova et al., 2005] while the Bergaul intrusion compositionally ranges from diorite-granodiorite to granite and some of the zircon cores from this intrusion indicate inheritance of 2.84 Ga [Bibikova et al., 2005].

Koitere, Kuittila, Ilomantsinjärvi, Pjozero, Njuk-Bolshozero, Amindomoj, Tasanvaara, Sysmänjärvi and Jalonvaara plutons (Fig. 2, Table 1) are located in the Central Karelian sub-province [Lobach-Zhuchenko et al., 2005; Kovalenko et al., 2005; Heilimo et al., 2013] constituting the Central Sanukitoid zone. There are two age groups of sanukitoids reported in this zone with a majority having ages of 2.73-2.71 Ga, which makes them younger than the Eastern zone sanukitoids, but older than the Western zone sanukitoid intrusions. In addition, most of the larger sanukitoid intrusions like Pjozero, Njuk-Bolshozero are in the central zone and have the same age. The second group of sanukitoids ( 3 intrusions) in this zone is aged 2.75-2.74 Ga (Fig. 2, Table 1) and located in the southern part of the central zone. The greenstone complexes in the Central Karelian sub-province (e. g. Ilomantsi) with arc-related volcanites were formed around $\sim 2.75-2.73 \mathrm{Ga}$ i. e. together with the older generation of sanukitoids [SorjonenWard, 1993; Hölttä et al., 2012, 2017].

The Western Sanukitoid zone [Bibikova et al., 2005; Lobach-Zhuchenko et al., 2005] in the Western sub-province consists of Kaapinsalmi, Raate, Kaartojärvet, Kurgelampi, Loso, Arola, Siikalahti and Nilsiä sanukitoid intrusions (Fig. 2). The age of sanukitoids in this zone ranges from $2.72 \mathrm{Ga}$ to $2.71 \mathrm{Ga}$ (in some cases up to $2.68 \mathrm{Ga}$; Table 1). Porphyritic granodiorites in Nilsiä were first studied by Halla [2005] and were classified as sanukitoids [Halla et al., 2009]. Later, based on geochemical data, several felsic granitoids were considered to be part of the sanukitoids series including Kartojärvet [Käpyaho et al., 2006]. A majority of the sanukitoids in this zone are intermediate to felsic except for gabbros reported from Kaartojärvet [Samsonov et al., 2004; Bibikova et al., 2005; Heilimo et al., 2011, 2013]. These sanukitoids are slightly older than the 2.73-2.66 Ga granodioritegranite-monzogranite (GGM) suite, 2.71 Ga alkaline gabbroids and ca 2.7 Ga quartz diorites as in the East Karelian sub-province [Hölttä et al., 2014; Mikkola et al., 2017 and references therein]. All these plutonic complexes excluding sanukitoids formed during the accretion-collision stage of crustal evolution. It is to be noted that the signatures of the Neoarchean (2.71-2.69 Ga) collisional orogen in the Belomorian Belt (Fig. 2), such as high-grade (kyanite sub-faces) metamorphism, migmatization, collison-type granites and nappe tectonics [Slabunov, 2008; Slabunov et al., 2006a, b, 2016; Hölttä et al., 2014], can also be observed in the western part of the craton [Mikkola et al., 2017]. The period between 2.72-2.71 Ga, which preceded the Belomorian collision, saw the formation of arc-type felsic volcanites (Kichani area of the Tikshozero belt), and Gridino eclogite in the Belomorian Belt [Hölttä et al., 2014; Li et al., 2015 and reference there]. The forming of Nurmes paragneisses may be one of the manifestations of this event in the Western Karelian subprovince. Therefore, the generation of sanukitoids in the Western zone preceded the collision and was connected with the last subduction process.

\section{Bundelkhand Craton}

Sanukitoids in Central India have recently been reported from western as well as eastern part of the Bundelkhand Craton. All sanukitoid variet- 
ies reported in Bundelkhand have been emplaced within a short time span (2.56 to $2.54 \mathrm{Ga}$ [Joshi et al., 2017]) and are much younger than those found in Karelia. In Central Bundelkhand, these sanukitoid intrusions are found along the narrow discontinuous belt running from Karera in the east to Mahoba in the west, parallel to the Central Bundelkhand Greenstone belt (Fig. 3). These intrusions are majorly felsic bodies belonging to the Low Silica High Magnisium rich granitoids (LSHM) and range compositionally from granodiorites to, less commonly, monzogranites. These LSHM granitoids have been geochemically classified into three subgroups: Sanukitoid granodiorites (2.56 and $2.55 \mathrm{Ga}$ ), Closepet granodiorites $(2.56 \mathrm{Ga})$ and sanukitoid monzogranites $(2.54 \mathrm{Ga})$ on the basis of their rare earth element abundances [Joshi et al., 2017]. The sanukitoids in this belt have similar ages and might have been generated as a single phase. All the reported sanukitoid varieties show slight deformation features like gneissic appearance and presence of schliren. An important feature of these sanukitoids is that they are contemporaneous to the felsic volcanics from $\mathrm{Ba}$ bina, which have been dated at $\sim 2.54 \mathrm{Ga}$ [Singh, Slabunov, 2015; Singh et al., 2018].

Sanukitoids from Eastern Bundelkhand are exposed near Khajuraho and Mahoba and range from mafic to felsic intrusions varying compositionally from monzogranites through monzodiorite to granodiorites. All these intrusions are coarse grained to porphyritic with numerous mafic enclaves. A majority of the sanukitoid type granodiorites in this zone intrude the $3.33 \mathrm{Ga}$ TTGs exposed near Mahoba while the sanukitoid type monzogranites mostly intrude the sanukitoid type monzodiorites and High Silica Low magnesium (HSLM) monzograites near Khajuraho. An emplacement age of $2.54 \mathrm{Ga}$ and 2.56 has been suggested by Joshi et al. [2017] for sanukitoid monzogranites and HSLM monzogranites while no age determinations have been done on the monzodiorite body.

Sanukitoid intrusions from the Western Bundelkhand Craton are essentially Sanukitoid granodiorites and Closepet granodiorites and are exposed near Babina, Orccha and Karera. These intrusions are commonly associated with mafic magmatic enclaves [Ramiz and Mondal, 2017]. Closepet granodiorites have an emplacement age of $2.56 \mathrm{Ga}$ with some inherited zircon cores with older ages (2.84 and $2.91 \mathrm{Ga})$ suggesting crustal inheritance [see Joshi et al., 2017 for review] while the sanukitoid granodiorites have ages $(2.56$ and $2.55 \mathrm{Ga}$ ) similar to those reported from the eastern part. It is also noted that as in the case of Karelian sanukitoids the Bundelkhand counterparts also have similar age as reported for vol- canic rocks from the Bundelkhand craton [Singh and Slabunov, 2015].

\section{Comparitive geochemistry/discussion}

\section{Petrography and Mineral Chemistry}

Mineral chemistry studies of sanukitoids from the Kurgelampi post-tectonic intrusion (Western zone) and Panozero, Elmus, Sharavalampi and Khizhjarvi intrusions (eastern zone) were done by Lobach-Zhuchenko et al. [2005, 2008] and Egorova [2014]. Major mineral assemblages of these intrusions are plagioclase, quartz, hornblende (which was altered to biotite) and K-feldspar while clinopyroxene is reported from the mafic-ultramafic rocks of the Panozero intrusion (Table 2). Apatite, sphene, carbonate, zircon, epidote and opaques are the main accessory phases reported. Plagioclase varies from labradorite to oligoclase while micas are high $\mathrm{Mg}$-biotite and some phlogopite. Amphiboles are mostly calcic, ranging from Mg-hornblende, edenite, pargasite, with actinolite and tremolite rims. It is suggested that actinolite and biotite rims in hornblende were probably formed due to metamorphic imprint during the Svecofennian orogeny [Lobach-Zhuchenko et al., 2005]. Pressures of $1.6 \pm 0.6 \mathrm{kbar}$ at the time of amphibole crystallization are calculated, indicating shallow level crystallization [Lobach-Zhuchenko et al., 2008].

The dominant mineral assemblage in sanukitoids from Bundelkhand are quartz, feldspar, biotite, and hornblende (Table 2). Accessory minerals include apatite, Fe-oxides, chlorite, titanite, allanite, zircon, and epidote [Mondal et al., 2002; Joshi, 2014]. Plagioclase composition in these granitoids ranges from $A b_{98} A n_{1}$ to $A b_{70} A n_{30}$ while potash feldspars are rich in $\mathrm{K}_{2} \mathrm{O}$ and are mainly sanidine. Mica in Bundelkhand sanukitoids is mainly Mg-rich biotite while all the analyzed amphiboles are calcic and belong to the group of calcium amphiboles [Joshi, 2014]. Chemical variation in these amphiboles ranges from magnesio-hornblende to ferro-hornblende and edinite to ferro edinite [Joshi, 2014].

\section{Major and Trace Element}

General aspects of major element data of sanukitoids from the Karelian and Bundelkhand cratons are shown in Table 2 and Fig. 4 . It is noted that Karelian sanukitoids show a wide variation in silica content as compared to sanukitoids from the Bundelkhand craton. Sanukitoids from the Eastern Sanukitoid Zone (Karelian Craton) show maximum variation in terms of major oxides, however, there is

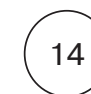


Table 2. Comparitive mineralogy and geochemistry of Bundelkhand and Karelian Sanukitoids

\begin{tabular}{l|l|l|l}
\hline Feature & Bundelkhand sanukitoids & East Karelian Sanukitoids & Central/West Karelian Sanukitoids \\
\hline Rock type & $\begin{array}{l}\text { Monzodiorite, granodiorite } \\
\text { and granite }\end{array}$ & $\begin{array}{l}\text { Ultramafic to felsic, lamprophyres } \\
\text { and associated syenites }\end{array}$ & $\begin{array}{l}\text { Gabbro, tonalitie, granodiorites, } \\
\text { quartz diorites and lamprophyres }\end{array}$ \\
\hline $\mathrm{SiO}_{2}$ range & $52.19-71.86$ wt. \% & $45.60-70.75$ wt. \% & $52.30-71.03$ wt. \% \\
\hline $\mathrm{Eu} / \mathrm{Eu}^{*}$ & 0.68 & 0.92 & 0.79 \\
\hline $\mathrm{Ba}+\mathrm{Sr}($ Avg. $)$ & $1328 \mathrm{ppm}$ & $2276 \mathrm{ppm}$ & $1890 \mathrm{ppm}$ \\
\hline $\mathrm{Ni} \mathrm{Cr}(\mathrm{Avg})$ & & & \\
\hline $\mathrm{Mg} \#($ Avg $)$ & 45.05 & 53.4 & 51.27 \\
\hline$(\mathrm{La} / \mathrm{Yb}) \mathrm{N}(\mathrm{Avg})$ & 20.35 & 31.08 & 31.74 \\
\hline $\mathrm{Age}$ & $2.54-2.56 \mathrm{Ga}$ & $2.74 \mathrm{Ga}$ & $2.71 \mathrm{Ga}$ \\
\hline
\end{tabular}
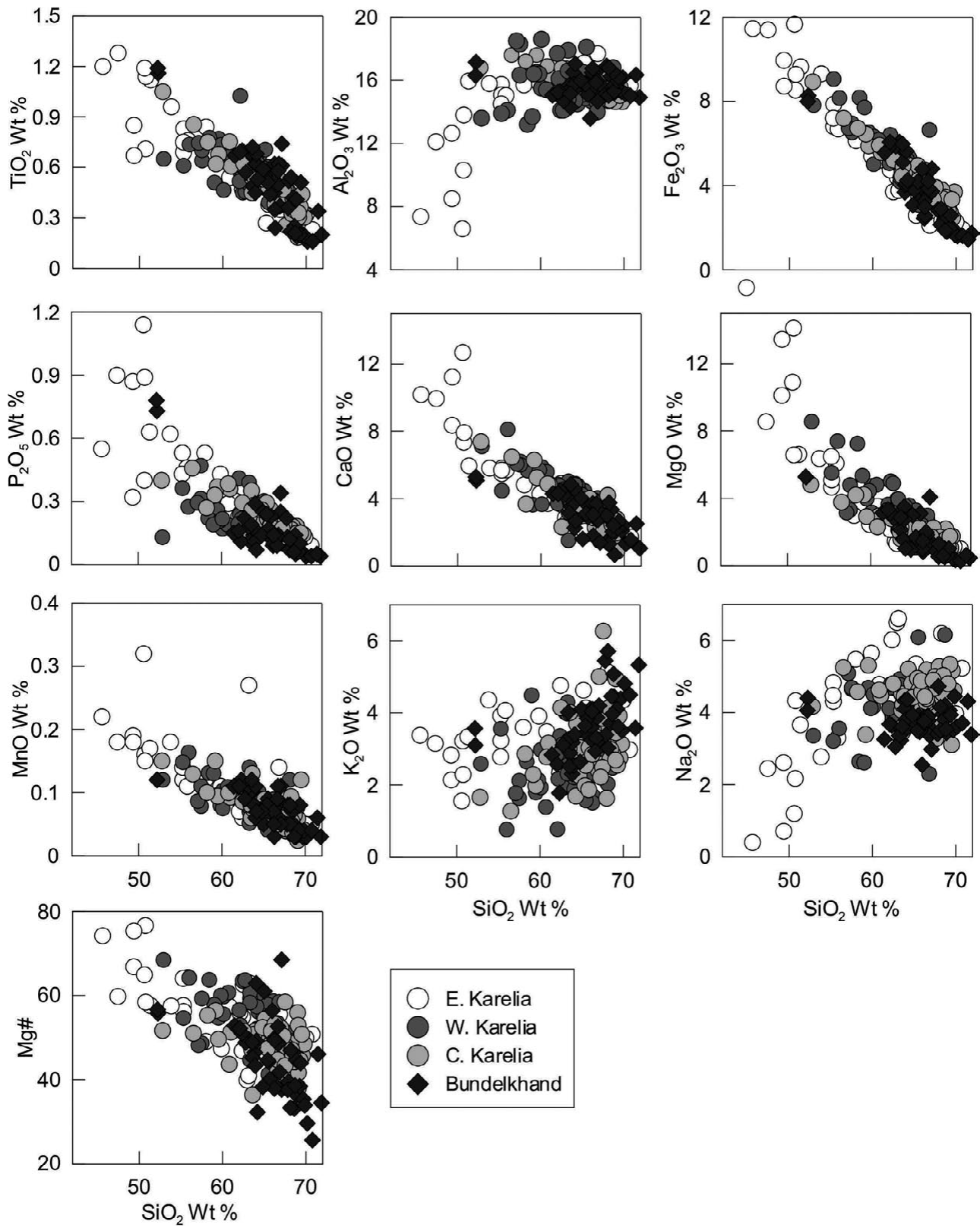

Fig. 4. Harker-type diagrams for major oxides and Mg\# involving $\mathrm{SiO}_{2}$ wt $\%$ as differentiation indices for sanukitoids from the Karelian and Bundelkhand Cratons. Data for Karelian sanukitoids and Bundelkhand sanukitoids are from [Vaasjoki et al., 1993; Halla, 2005; Heilimo et al., 2011, 2013 and references therein; Joshi et al., 2017] 

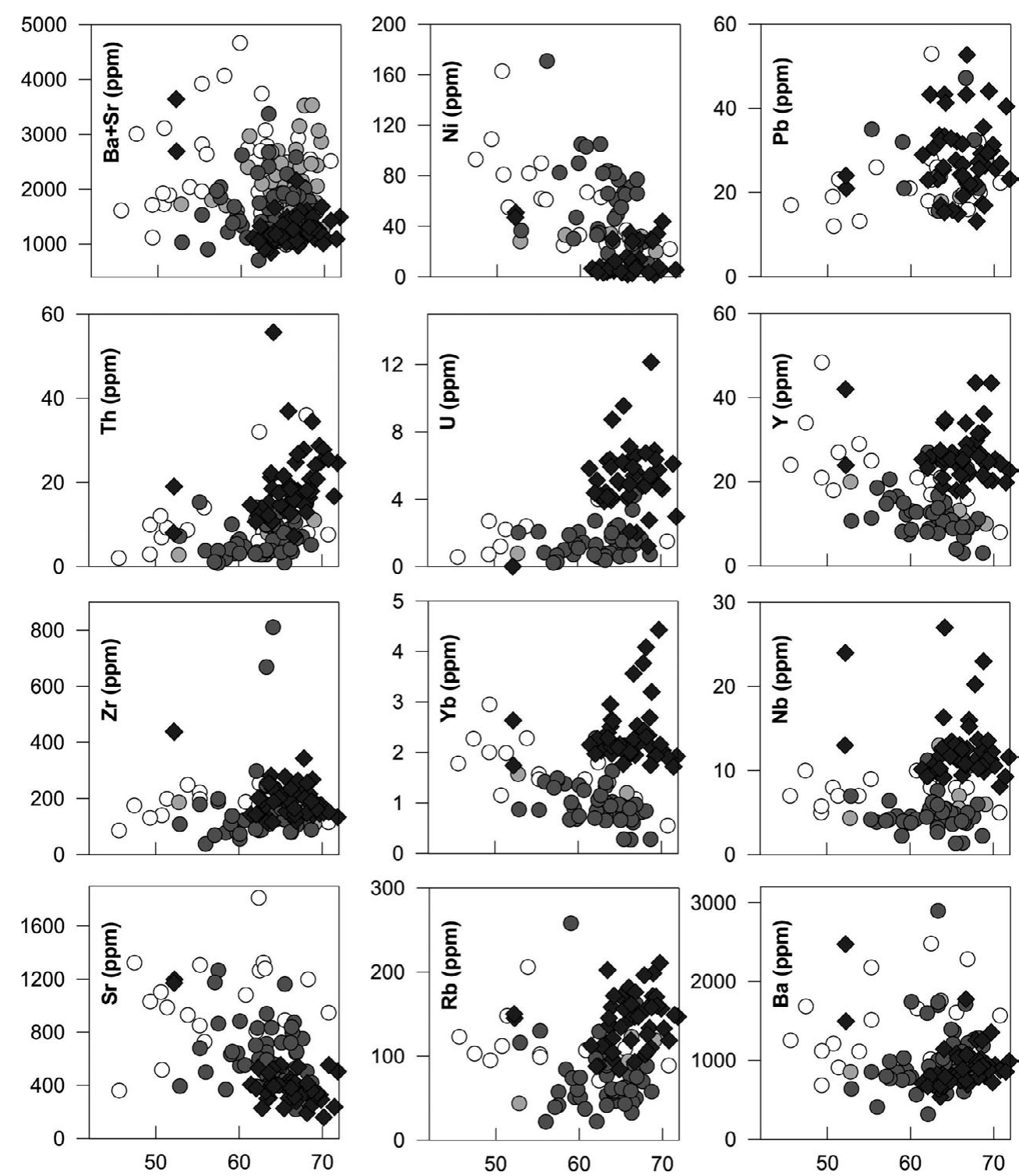

Fig. 5. Harker-type diagrams for trace elements involving $\mathrm{SiO}_{2}$ wt $\%$ as differentiation indices for sanukitoids from the Karelian and Bundelkhand Cratons. Data for Karelian sanukitoids and Bundelkhand sanukitoids are from [Vaasjoki et al., 1993; Halla, 2005; Heilimo et al., 2011, 2013 and references therein; Joshi et al., 2017]

close similarity between Bundelkhand sanukitoids and sanukitoids from the Central and Western (Karelian) Sanukitoid Zone as they show substantial overlap at similar silica contents. It can be noted that there are more mafic varieties in the Karelian data set versus more granodiorites and granites in the Bundelkhand sanukitoid collection (Fig. not shown).

In terms of trace elements (Fig. 5), notable difference can be seen in sanukitoids from the Karelian craton as compared to those from the Bundelkhand craton. Sanukitoids from Bundelkhand have significantly higher concentrations of Th, $U$, $\mathrm{Y}, \mathrm{Nb}, \mathrm{Rb}$ and are depleted in $\mathrm{Ni}$ concentrations. A majority of the Karelain samples have higher $\mathrm{Sr}$ and $\mathrm{Ba}$ concentrations, however, some overlap can be seen between samples from Bundelkhand and Central and Western Sanukitoids from Karelia. In the mantle normalized trace element diagram (Fig. 6), all the samples show an increase in incompatible elements toward the left (mostly LILEs), negative $\mathrm{Nb}, \mathrm{P}$ and $\mathrm{Ti}$ anomalies and positive $\mathrm{Pb}$ anomaly. Bundelkhand sanukitoids can be distinguished from Karelian sanukitoids in their lower Ba contents and higher $Y$ and HREE concentration. In the chondrite normalized rare earth patterns (Fig. 7), all the samples show enriched LREEs and depleted HREEs. Sanukitoids from Eastern Karelia show slight to no Eu anomalies while those from Western Karelia and Bundelkhand show slight 


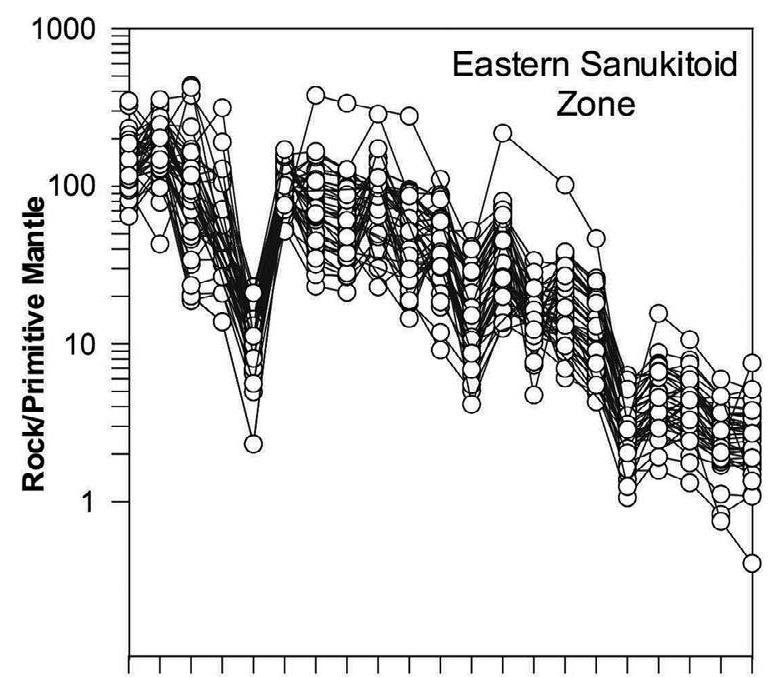

Rb Ba Th U NbK LaCe PbPrSr P NdZrSmEuTiDy Y YbLu

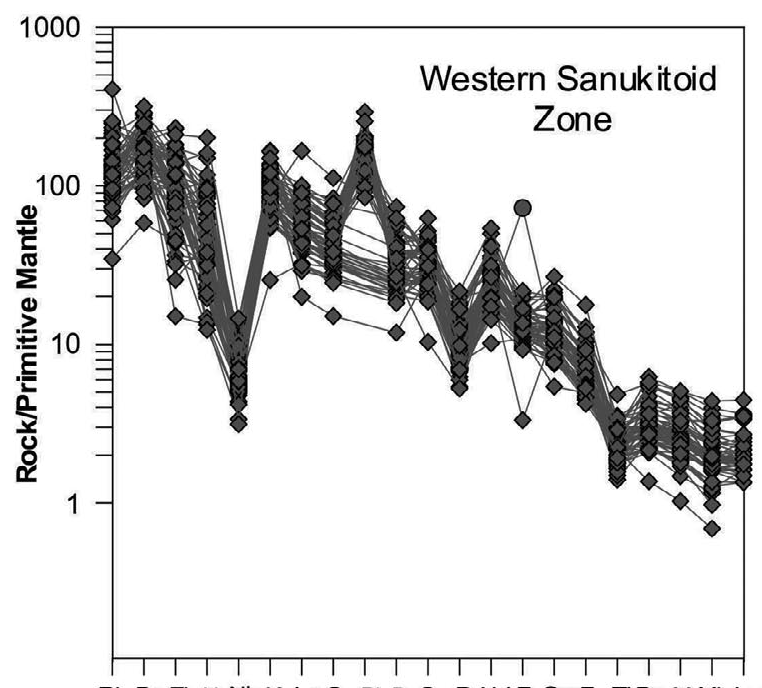

Rb Ba Th U Nb K La Ce PbPr Sr P NdZr SmEu TiDy Y YbLu

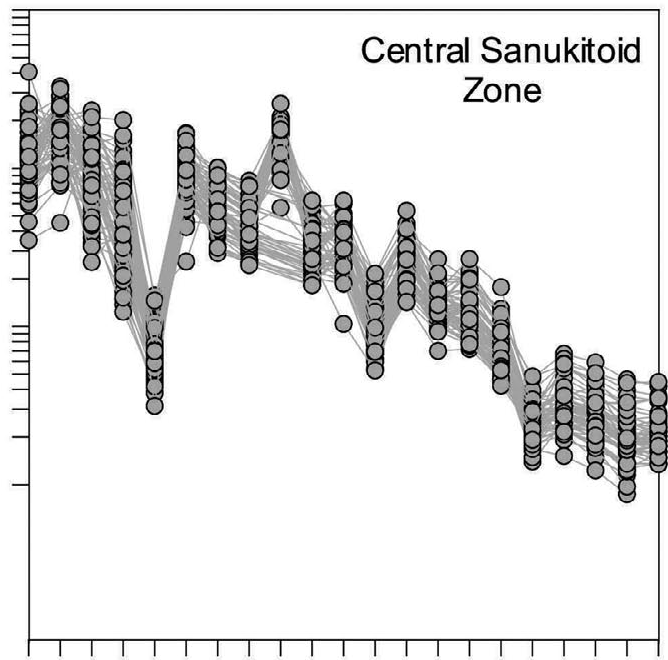

Rb Ba Th U Nb K La Ce PbPrSr P NdZrSmEuTiDy Y YbLu

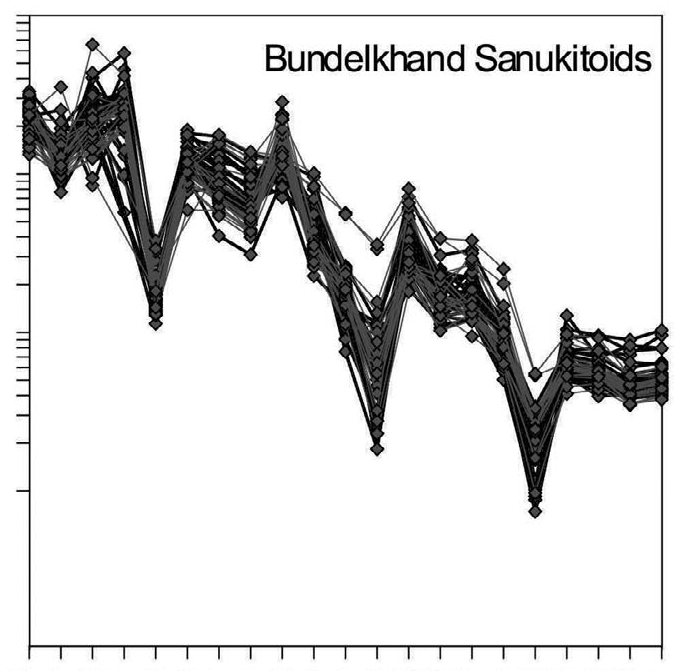

Rb Ba Th U Nb K LaCe PbPrSr P NdZr SmEuTiDy Y YbLu

Fig. 6. Sanukitoids from the Karelian and Bundelkhand Cratons plotted on a primitive mantle-normalized spider diagram. Normalization values are from Sun and McDonough [1989]. Data for Karelian sanukitoids and Bundelkhand sanukitoids are from [Vaasjoki et al., 1993; Halla, 2005; Heilimo et al., 2011, 2013 and references therein; Joshi et al., 2017]

to variable Eu anomalies. Bundelkhand sanukitoids can be differentiated from those of the Karelian craton in their slightly elevated HREE contents.

\section{Petrogenesis of Karelian and Bundelkhand Sanukitoids}

In most Archean terranes, granitic plutons were emplaced after the main phase of TTG magmatism. It has often been suggested that the granitic magmas were formed by reworking of TTGs [Sylvester, 1994; Moyen et al., 2003], partial melting of meta-tonalites [Skjerlie and Johnston, 1993; Patiño Douce, 2005; Watkins et al., 2007] or as a result of interaction between mantle-derived magmas and anatectic crustal melts [Jayananda et al., 1995; Moyen et al., 2001; Halla, 2005]. Variable sources, viz. mantle peridotite, basaltic slab, preexisting crust and terrigenous sediments, are considered responsible for the genesis of late Archean sanukitoids in most cratons around the world [Kovalenko et al., 2005; Halla, 2005; Rapp et al., 2010; Oliveira et al., 2011; Laurent et al., 2011; Heilimo et al., 2011, 2013].

Fowler and Rollinson [2012] considered Caledonian high $\mathrm{Ba}-\mathrm{Sr}$ granites from the Northern Highlands of Scotland as petrological and compositional equivalents of Neoarchean sanukitoids. They further suggested sediment subduction and slab breakoff caused melting in the subcontinental lithospheric mantle (SCLM) as a possible mechanism for their generation. Lobach-Zhuchenko et al. [2008] also proposed slab breakoff and subsequent mantle upwelling as the trigger for 


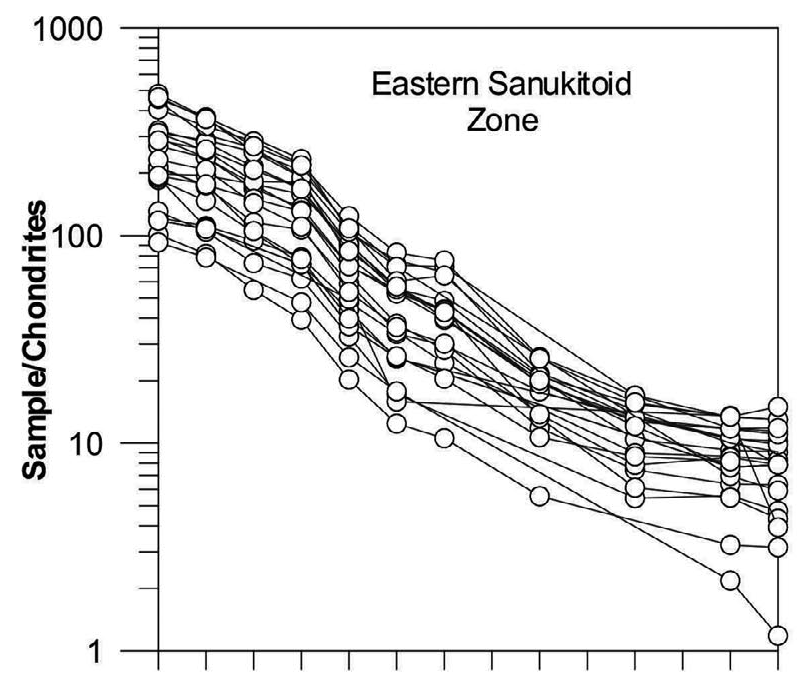

La Ce Pr NdSmEu Gd Tb Dy Ho Er Tm Yb Lu

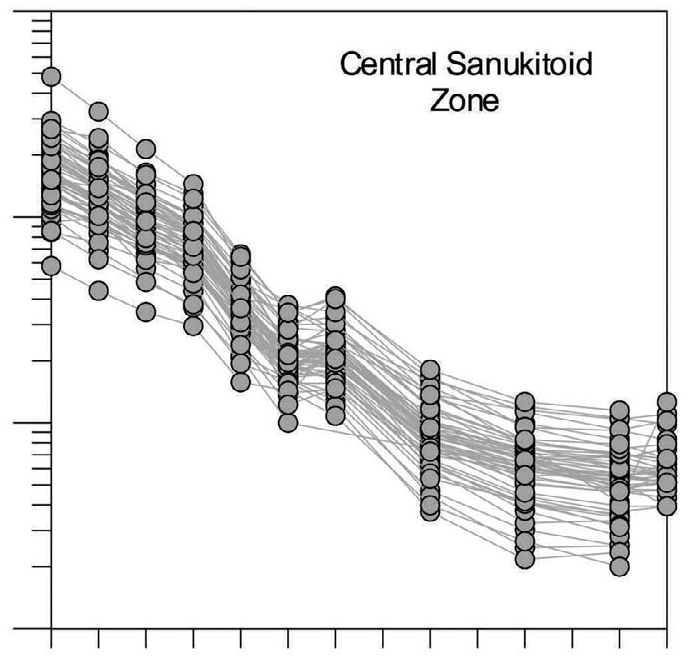

La Ce Pr NdSmEu Gd Tb Dy Ho Er Tm Yb Lu

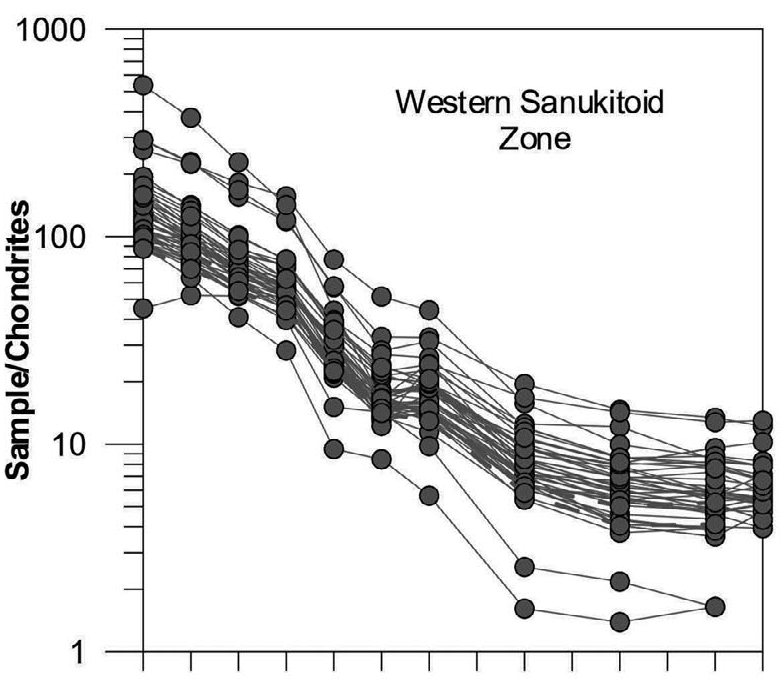

La Ce Pr NdSmEu Gd Tb Dy Ho Er Tm Yb Lu

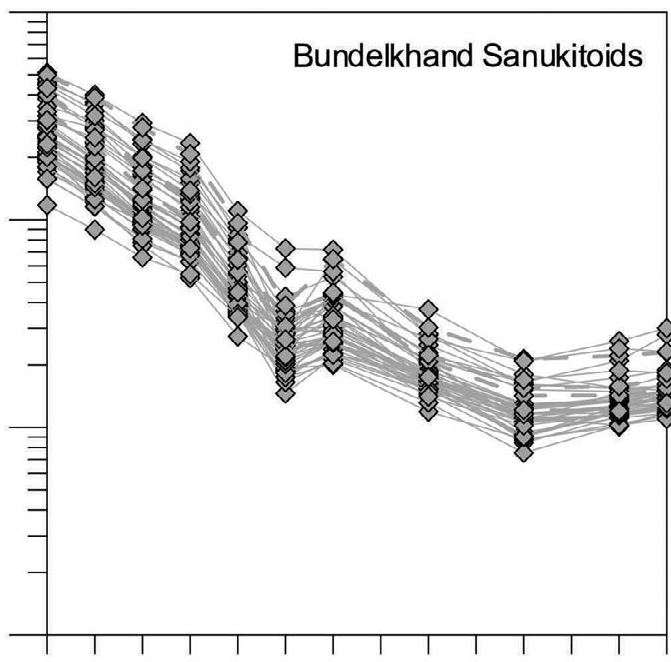

La Ce Pr NdSmEu Gd Tb Dy Ho Er Tm Yb Lu

Fig. 7. Sanukitoids from the Karelian and Bundelkhand Cratons plotted on a chondrite normalized spider diagram. Normalization values are from Sun and McDonough [1989]. Data for Karelian sanukitoids and Bundelkhand sanukitoids are from [Vaasjoki et al., 1993; Halla, 2005; Heilimo et al., 2011, 2013 and references therein; Joshi et al., 2017]

Neoarchean sanukitoid magmatism in Karelia while Heilimo et al. [2013] suggested well-homogenized enriched SCLM as a potential source. Phlogopite-bearing Iherzolite is suggested as the source of Karelian sanukitoids and related intrusions, which explains elevated LILE contents, while the enrichment of compatible and incompatible elements can be attributed to subduction related processes that were operative [Stern and Hanson, 1991; Lobach-Zhuchenko et al., 2008] .

Geochemical data from Bundelkhand sanukitoids suggest their geochemical affinity with West Karelian sanukitoids. However, there are some compositional differences in Bundelkhand sanukitoids viz. lower $\mathrm{Na}_{2} \mathrm{O}, \mathrm{Ba}+\mathrm{Sr}$ and $\mathrm{Ni}$ contents. These may be due to their formation in the shallow crust with relatively less inputs from the mantle. The emplacement ages of Bundelkhand sanukitoids $(2.56-2.53 \mathrm{Ga})$ are younger than those reported in Karelia $(2.74-2.72 \mathrm{Ga})$ but similar to the sanukitoid ages (2.95 to $2.54 \mathrm{Ga}$ ) from the rock record. The lack of isotopic data from Bundelkhand sanukitoids limits our conclusion regarding the exact processes that could have been responsible for their genesis. It has been suggested that Bundelkhand sanukitoids were produced in subduction environment and were affected by two different metasomatic events. The first subduction event caused enrichment of the mantle, 
which was followed by slab breakoff (as in the case of Caledonian high $\mathrm{Ba}-\mathrm{Sr}$ granites), which allowed upwelling of the fluid and flux to the overlying crust thereby causing remelting and producing various potassic granites.

\section{Conclusions}

1) Sanukitoid massifs from the Karelian and Bundelkhand Cratons are localised in linear zones and are contemporaneous to arc-type volcanics, probably pointing towards similar geodynamic processes responsible for their formation.

2) Geochemically, Neoarchean (2.56-2.53 Ga) sanukitoids from Bundelkhand are similar to those from the Central and Western Karelian zones $(2.72-2.68 \mathrm{Ga})$ while they are less differentiated as compared to sanukitoids $(2.74-2.73 \mathrm{Ga})$ from the Eastern Karelian Zone. Geochemical similarities in sanukitoids from both these cratons indicate that similar petrogenetic processes might have been responsible for their formation.

3) Neoarchean sanukitoid magmatism in both the cratons is associated with subduction related processes followed by slab breakoff which preceded the accretion-collision events.

This work is a contribution to Russian Foundation for Basic Research grants 15-35-50162, 17-55-45005 ИНД-а and to project IG KarNC RAS № A18-118020290085-4.

We thank the Director (Prof. Vladimir Shchiptsov) of the Institute of Geology Karelian RC RAS and the Director of the ESSO-National Centre for Earth Science Studies for support.

\section{References}

Acharya S. K. A plate tectonic model for Proterozoic crustal evolution of Central Indian Tectonic Zone. Gond. Geol. Mag. 2003. Vol. 7. P. 9-31.

Adam J., Rushmer T., O'Neil J., Francis D. Hadean greenstones from the Nuvvuagittuq fold belt and the origin of the Earth's early continental crust. Geology. 2012. Vol. 40. P. 363-366.

Arth J. G., Hanson G. N. Quartz diorites derived by partial melting of eclogite or amphibolite at mantle depths. Contrib. Mineral. Petrol. 1972. Vol. 37. P. 161-174.

BalaganskyV., ShchipanskyA., Slabunov A. I., Gorbunov I., Mudruk S., Sidorov M., Azimov P., Egorova S., Stepanova A., Voloshin A. Archean Kuru-Vaara eclogites in the northern Belomorian Province, Fennoscandian Shield: crustal architecture, timing and tectonic implications. Int. Geol. Rev. 2015. Vol. 57(11-12). P. 1543-1565.

Barton J. M. Jr., Doig R., Smith C. B., Bohlender F., Van Reenen D. D. Isotopic and REE characteristics of the intrusive charnoenderbite and enderbite geographi- cally associated with the Matok Pluton, Limpopo Belt, southern Africa. Precambrian Res. 1992. Vol. 55(1-4). P. 451-467.

Basu A. K. Geology of Parts of the Bundelkhand Granite Massif, Central India. Rec. Geol. Surv. India Spec. Publ. 1986. Vol. 117(2). P. 61-124.

Bibikova E. V., Arestova N. A., Ivanikov V. V., Claesson S., Petrova A. Yu., Levchenkov O. A. Isotopic geochronology of the Archean Posttectonic Association of sanukitoids, syenites, and granitoids in Central Karelia. Petrology. 2006. Vol. 14(1). P. 39-49.

Bibikova E. V., Bogdanova S. V., Glebovitskii V. A., Claesson S., Skiold T. Evolution of the Belomorian Belt: NORDSIM U-Pb zircon dating of the Chupa Paragneisses, magmatism and metamorphic stages. Petrology. 2004. Vol. 12(3). P. 195-210.

Bibikova E. V., Kirnozova T. I., Makarov V., Borisova E. Yu., Slabunov A. I., Kavelich V. I. U-Pb Geochronology and major-element chemistry of a diorite-plagiogranitic batholith in Northern Karelia. Geochem. Int. 1997. Vol. 35(11). P. 1021-1027.

Bibikova E. V., Petrova A., Claesson S. The temporal evolution of sanukitoids in the Karelian Craton, Baltic Shield: an ion microprobe U-Th-Pb-isotopic study of zircons. Lithos. 2005. Vol. 79. P. 129-145.

Bleeker W. The late Archean record: a puzzle in ca. 35 pieces. Lithos. 2003. Vol. 71. P. 99-134.

Brown G. C. Processes and problems in the continental lithosphere: geological history and physical implications. Snelling N. (eds). Geochronol. Geol. Rec. Spec. Publ. Geol. Society, London, 10. 1985. P. 326-334.

Brown M. Metamorphic conditions in orogenic belts: a record of secular change. Int. Geol. Rev. 2007. Vol. 49. P. 193-234.

Champion D. C., Sheraton J. W. Geochemistry and $\mathrm{Nd}$ isotope systematics of the Archean granites of Eastern Goldfields, Yilgarn Craton, Australia: implications for Archean crustal growth processes. Precambrian Res. 1997. Vol. 83. P. 109-132.

Chekulaev V. P., Arestova N. A., Berezhnaya N. G., Presnyakov S. L. New data on the age of the oldest tonalite - trondhjemite association in the Baltic Shield. Stratigr. Geol. Correl. 2009. Vol. 17(2). P. 230-234.

Chekulaev V. P., Levchenkov O. A., Arestova N. A., Kovalenko A. V., Guseva N. S., Komarov A. N., Ivanikov V. V. Composition, age, and Sm - Nd systematics of high magnesium granitoids (sanukitoids) of the Panozero Pluton, Karelia. Geochem. Int. 2003. Vol. 41(8). P. 741-752.

Condie K. C. TTGs and adakites: are they both slab melts? Lithos. 2005. Vol. 80. P. 33-44.

Condie K. C. How to make a continent: thirty-five years of TTG research. Y. Dilek and H. Furnes (eds). Evolution of Archean Crust and Early Life. Modern Approaches in Solid Earth Sci. Vol. 7. Dordrecht: Springer, 2014. P. 179-194.

Condie K. C., Benn K. Archean geodynamics: similar to or different from modern geodynamics. Benn $K$, Mareschal J.-C., Condie K. C. (eds). Archean Geodynamics and Environments Geophysical Monograph. 2006. Vol. 164. P. 47-60.

CrawfordA.R. The Precambrian geochronology of Rajasthan and Bundelkhand, northern India. Can. J. Earth Sci. 1970. Vol. 7. P. 91-110. 
Daly J. S., Balagansky V. V., Timmerman M. J., Whitehouse M. J. The Lapland-Kola orogen: Palaeoproterozoic collision and accretion of the northern Fennoscandian lithosphere. Gee D. G., Stephenson R. A. (eds), European lithosphere dynamics. Geol. Society, London. Memoir, 32. 2006. P. 579-598.

De Wit M. J. On Archean granites, greenstones, cratons and tectonics: does the evidence demand a verdict? Precambrian Res. 1998. Vol. 91. P. 181-226.

Dmitrieva A. V., Kuleshevich L. V. Geological structure, Late Archean intrusive magmatism and metallogeny of the Ondozero-Segozero prospect, Karelia. Native Geol. 2018. Vol. 1. P. 40-54. (In Russ.).

Egorova Yu. S. The sanukitoids from Fenno-Karelian Province, Baltic Shield: geology, composition and sources. Dissertation, IPGG RAS. St. Petersburg, 2014. 209 p. (In Russ.).

Feio G. R. L., Dall'Agnol R. Geochemistry and petrogenesis of the Mesoarchean granites from the Canaã dos Carajás area, Carajás Province, Brazil: Implications for the origin of Archean granites. Lithos. 2012. Vol. 154. P. 33-52.

Foley S., Tiepolo M., VanucciR. Growth of early continental crust controlled by melting of amphibolite in subduction zones. Nature. 2002. Vol. 417. P. 837-840.

Foley S. A trace element perspective on Archean crust formation and on the presence or absence of Archean subduction. K. C. Condie and V. Pease (eds). When Did Plate Tectonics Begin? Geol. Society of America Special Paper, 440. 2008. P. 31-50.

Fowler M., Rollinson $\mathrm{H}$. Phanerozoic sanukitoids from Caledonian Scotland: implications for Archaean subduction. Geology. 2012. Vol. 40. P. 1079-1082.

Frost C. D., Frost B. R., Chamberlain K. R., Hulsebosch T. P. The Late Archean history of the Wyoming province as recorded by granitic magmatism in the Wind River Range, Wyoming. Precambrian Res. 1998. Vol. 89. P. $145-173$.

Guseva N. S., Lobach-Zhucenko S. B., Skublov S. G. Larionov A. N. Formation time of Panozero sanukitoids complexe (Central Kareia). Isotopic systems and geological time. Proceed. IV All-Russ. Conf. on isotopic geol. St. Peterburg. 2009. Vol. 1. P. 156-159. (In Russ.).

Halla J. Late Archean high-Mg granitoids (sanukitoids) in the southern Karelian domain, eastern Finland: $\mathrm{Pb}$ and $\mathrm{Nd}$ isotopic constraints on crust-mantle interactions. Lithos. 2005. Vol. 79. P. 161-178.

Halla J., van Hunen J., Heilimo E., Hölttä P. Geochemical and numerical constraints on Neoarchean plate tectonics. Precambrian Res. 2009. Vol. 174 P. $155-162$

Halla J., Whitehouse M. J., Ahmad T., Bagai Z. Archaean granitoids: an overview and significance from a tectonic perspective. Crust-mantle interactions and granitoid diversification: insights from Archaean Cratons. Geol. Society, London. Special Publications, 449. 2017. Vol. P. 1-18.

Hamilton W. B. Archean magmatism and tectonics were not products of plate tectonics. Precambrian Res. 1998. Vol. 91. P. 143-179.

Hamilton W. B. Plate tectonics began in Neoproterozoic time and plumes from deep mantle have never operated. Lithos. 2011. Vol. 123. P. 1-20.
Harris L., Bédard J. Crustal Evolution and Deformation in a not-plate - tectonic Archaean Earth: comparisons with Venuse. Dilek Y., Furnes H. (eds), Evolution of Archean Crust and Early Life, Modern Approaches in Solid Earth Sci. Vol. 7. Springer, 2014. P. 215-291.

Heilimo E., Mikkola P., Halla J. Age and petrology of the Kaapinsalmi sanukitoid intrusion in Suomussalmi, Eastern Finland. Bull. Geol. Soc. Finland. 2007. No. 79 P. 117-125.

Heilimo E., Halla J., Huhma H. Single-grain zircon $\mathrm{U}-\mathrm{Pb}$ age constraints of the eastern and western sanukitoid zones in the Finnish part of the Karelian Province. Lithos. 2011. Vol. 121. P. 87-99.

Heilimo E., Halla J., Andersen T., Huhma H. Neoarchean crustal recycling and mantle metasomatism: Hf$\mathrm{Nd}-\mathrm{Pb}-\mathrm{O}$ isotope evidence from sanukitoids of the Fennoscandian Shield. Precambrian Res. 2013. Vol. 228. P. 250-266

Heilimo E., Halla J., Hölttä P. Discrimination and origin of the sanukitoid series: geochemical constraints from the Neoarchean western Karelian Province (Finland). Lithos. 2010. Vol. 115. P. 27-39.

Herzberg C., Condie K., Korenaga J. Thermal history of the Earth and its petrological expression. EPSL. 2010 Vol. 292. P. 79-88.

Hoffmann J. E., Munker C., Naeraa T., Rosing M. T., Herwartz D., Garbe-Schonberg D., Svahnberg H. Mechanisms of Archean crust formation inferred from highprecision HFSE systematics in TTGs. Geochim. Cosmochim. Acta. 2011. Vol. 75. P. 4157-4178.

Hoffmann J. E., NagelT. J., Münker C., Næraa T., Rosing M. T. Constraining the process of Eoarchean TTG formation in the Itsaq Gneiss Complex, southern West Greenland. EPSL. 2014. Vol. 388. P. 374-386.

Hölttä P., Balagansky V., Garde A. A., Mertanen S., Peltonen P., Slabunov A. I., Sorjonen-Ward P. Archean of Greenland and Fennoscandia. Episodes. 2008. Vol. 31(1). P. 1-7.

Hölttä P., Heilimo E., Huhma H., Kontinen A., Mertanen S., Mikkola P., Paavola J., Peltonen P., Semprich J., Slabunov A., Sorjonen-Ward P. The Archaean of the Karelia Province in Finland. Geol. Survey of Finland. Special Paper, 54. 2012. P. 21-72.

Hölttä P., Heilimo E., Huhma H., Kontinen A., Mertanen S., Mikkola P., Paavola J., Peltonen P., Semprich J., Slabunov A., Sorjonen-WardP. The Archaean Karelia and Belomorian Provinces, Fennoscandian Shield. DilekY., Furnes H. (eds). Evolution of Archean Crust and Early Life. Modern Approaches in Solid Earth Sci. Vol. 7. Dordrecht: Springer, 2014. P. 55-102.

Hölttä P., Heilimo E., Huhma H., Kontinen A., Lauri L., SlabunovA. Paleoarchean rocks in the Fennoscandian Shield. Van KranendonkM. J., Bennett V. C., Hoffmann J. E. (eds.). Earth's oldest rocks. Amsterdam: Elsevier, 2019. P. 819-836. doi: 10.1016/ B978-0-444-63901-1.00032-0

Hölttä P., Lehtonen E., Lahaye Y., Sorjonen-Ward P. Metamorphic evolution of the llomantsi greenstone belt in the Archaean Karelia Province, eastern Finland Halla J., Whitehouse M. J., Ahmad T., Bagai Z. (eds). Crust-Mantle Interactions and Granitoid Diversification: Insights from Archaean Cratons. Geol. Society, Lon- 
don. Special Publications, 449. 2017. P. 231-250. doi: 10.1144/SP449.7

Hölttä P., Paavola J. P-T-t development of Archaean granulites in Varpaisjärvi Central Finland I: effects of multiple metamorphism on the reaction history of mafic rocks. Lithos. 2000. Vol. 50. P. 97-120

Huhma H., Mänttäril., Peltonen P., Kontinen A., Halkoaho T., Hanski E., Hokkanen T., Hölttä P., Juopperi H., Konnunaho J., Lahaye Y., Luukkonen E., Pietikäinen K., Pulkkinen A., Sorjonen-WardP., Vaasjoki M., Whitehouse M. The age of the Archaean greenstone belts in Finland. Geol. Survey of Finland. Special Paper, 54. 2012. P. 73-174.

Ivanikov V. V. Archean syenites and monzonites from Karelia. Vestnik SPSU. Ser. 7. Geology and Geography. 1997. Vol. 1(7). P. 11-21.

Jahn B. M., Auvray B., Shen Q. H., Liu D.-Y., Zhang Z.-Q., Dong Y.-J., YeX.-J., Zhang Q.-Z., Cornichet J., Mace J. Archean crustal evolution in China: the Taishan complex, and evidence for juvenile crustal addition from long-termdepleted mantle. Precambrian Res. 1988. Vol. 38. P. 381-403. doi: 10.1016/0301-9268(88)90035-6

Jayananda M., Martin H., PeucatJ-J., Mahabaleswar $B$. Late Archaean crust-mantle interactions geochemistry of LREE-enriched mantle derived magmas. Example of the Closepet batholith, southern India. Contrib. Mineral. Petrol. 1995. Vol. 119. P. 314-329.

Jayananda M., Moyen J. F., Martin H., Peucat J. J., Auvray B., Mahabaleswar B. Late Archaean (2550$2520 \mathrm{Ma}$ ) juvenile magmatism in the Eastern Dharwar craton, southern India: constraints from geochronology, $\mathrm{Nd}-\mathrm{Sr}$ isotopes and whole rock geochemistry. Precambrian Res. 2000. Vol. 99(3-4). P. 225-254.

Joshi K. B. Petrological, geochemical and U-Pb zircon geochronological studies of the Bundelkhand granitoid complex, Central India: constraints on Archean crustal evolution. PhD Thesis, Dep. of Geol. University of Delhi, India, 2014. 310 p.

Joshi K. B., Bhattacharjee J., RaiG., Halla J., Ahmad T., Kurhila M., Heilimo E., Choudhary A. K. The diversification of granitoids and plate tectonic implications at the Archaean-Proterozoic boundary in the Bundelkhand Craton, Central India. Halla J., Whitehouse M. J., Ahmad T. and Bagai Z. (eds). Crust-Mantle Interactions and Granitoid Diversification: Insights from Archaean Cratons. Geol. Society, London. Special Publications, 449. 2017. P. 123-157. doi: 10.1144/SP449.8

Käpyaho A., Mänttäri I., Huhma H. Growth of Archaean crust in the Kuhmo district, eastern Finland: U-Pb and $\mathrm{Sm}-\mathrm{Nd}$ isotope constraints on plutonic rocks. Precambrian Res. 2006. Vol. 146. P. 95-119.

Käpyaho A., Molnár A. F., Sorjonen-Ward P., Mänttäri I., Sakellaris G., Whitehouse M. J. New U-Pb age constraints for the timing of gold mineralization at the Pampalo gold deposit, Archaean Hattu schist belt, eastern Finland, obtained from hydrothermally altered and recrystallised zircon. Precambrian Res. 2017. Vol. 289. P. 48-61.

Kaur P., Zeh A., Chaudhri N. Characterisation and U$\mathrm{Pb}-\mathrm{Hf}$ isotope record of the $3.55 \mathrm{Ga}$ felsic crust from the Bundelkhand Craton, northern India. Precambrian Res. 2014. Vol. 255. P. 236-244.
Kelemen P. B., Hanghøj K., Greene A. R. One view of the geochemistry of subduction related magmatic arcs, with an emphasis on primitive andesite and lower crust. In: Davis A. M., Holland H.D. and Turekian K. K. (eds). Treatise on Geochemistry. 2014. Vol. 2. P. 749-805.

Kontinen A., Käpyaho A., Huhma H., Karhu J., Matukov D. I., Larionov A., Sergeev S. A. Nurmes paragneisses in eastern Finland, Karelian Craton: provenance, tectonic setting and implications for Neoarchaean Craton correlation. Precambrian Res. 2007. Vol. 152. P. $119-148$.

Kovalenko A., Clemans J.D., Savatenkov V. Petrogenetic constraints for the genesis of Archaean sanukitoid suites: geochemistry and isotopic evidence from Karelia, Baltic Shield. Lithos. 2005. Vol. 79. P. 147-160.

KulikovV. S., SvetovS.A., SlabunovA. I., Kulikova V. V., Polin A. K., Golubev A. I., Gorkovets V. Ya., Ivashchenko V. I., Gogolev M. A. Geological map of Southeastern Fennoscandia (scale 1:750000): a new approach to map compilation. Trudy KarNTs RAN [Trans. KarRC RAS]. 2017. No. 2. P. 3-41. doi: 10.17076/geo444

Larionova Yu. O., Samsonov A. V., Shatagin K. N. Sources of Archean Sanukitoids (High-Mg Subalkaline Granitoids) in the Karelian Craton: Sm-Nd and RbSr Isotopic-Geochemical Evidence. Petrology. 2007. Vol. 15(6). P. 530-550.

Laurent O., Martin H., Doucelance R., Moyen J. F., Paquette J. L. Geochemistry and petrogenesis of highK "sanukitoids" from the Bulai pluton, Central Limpopo Belt South Africa: implications for geodynamic changes at the Archaean-Proterozoic boundary. Lithos. 2011. Vol. 123. P. 73-91.

Lauri L. S., Hellström F., Bergman S., Huhma H. et al. New insights into the geological evolution of the Archean Norrbotten province, Fennoscandian shield. Bull. Geol. Society of Finland, Special Vol. Abs. $32^{\text {nd }}$ Nordic Geol. Winter Meeting. Helsinki, 2016. 193 p.

Laurie A., Stevens G. Water present eclogite melting to produce Earth's early felsic crust. Chem. Geol. 2012. Vol. 314-317. P. 83-95.

Lehtonen E., Heilimo E., Halkoaho T., Käpyaho A., Hölttä $P$. U-Pb geochronology of Archaean volcanicsedimentary sequences inthe Kuhmo greenstone belt, Karelia Province - Multiphase volcanismfrom Mesoto Neoarchaean and a Neoarchaean depositional basin? Precambrian Res. 2016. Vol. 275. P. 48-69.

LiX., Zhang L., Wei C., Slabunov A. I. Metamorphic PT path and zircon U-Pb dating of Archean eclogite association in Gridino complex, Belomorian province, Russia. Precambrian Res. 2015. Vol. 268. P. 74-96.

Lobach-Zhuchenko S. B., Chekulaev V. P., Arestova N. A., Levskii L. K., Kovalenko A. V. Archean terranes in Karelia: geological and isotopic-geochemical evidence. Geotectonics. 2000. Vol. 34(6). P. 452-466.

Lobach-Zhuchenko S. B., Rollinson H. R., Chekulaev V. P., Arestova N. A., Kovalenko A. V., Ivanikov V. V., Guseva N. S., Sergeev S. A., Matukov D. I., Jarvis K. E. The Archaean sanukitoid series of the Baltic Shield: geological setting, geochemical characteristics and implications for their origin. Lithos. 2005. Vol. 79. P. 107-128.

Lobach-Zhuchenko S. B., Rollinson H. R., Chekulaev V. P., Savatenkov V. M., Kovalenko A. V., Martin H., 
Guseva N. S., Arestova N. A. Petrology of the Late Archaean, highly potassic, sanukitoid pluton from the Baltic Shield: insights into Late Archaean mantle metasomatism. J. Petrology. 2008. Vol. 49. P. 393-420.

Malviya V. P., Arima M., Pati J. K., Kaneko Y. First report of metamorphosed pillow lava in central part of Bundelkhand craton - an island arc setting of possible late Archaean age. Gondwana Res. 2004. Vol. 7. P. $1338-1340$.

Malviya V. P., Arima M., Pati J. K., Kaneko Y. Petrology and geochemistry of metamorphosed basaltic pillow lava and basaltic komatiite in the Mauranipur area: subduction related volcanism in the Archean Bundelkhand craton, Central India. J. Mineral. Petrol. Sci. 2006. Vol. 101. P. 199-217.

Martin H., Moyen J.-F. Secular changes in tonalite-trondhjemite granodiorite composition as markers of the progressive cooling of Earth. Geology. 2002. Vol. 30. P. 319-322.

Martin H., Moyen J.-F., Rapp R. The sanukitoids series: magmatism at the Archaean-Proterozoic transition. Earth and Environmental Science Trans. of the Royal Society of Edinburgh. 2010. Vol. 100. P. 15-33.

Martin H., Smithies R., Rapp R., Moyen J., Champion $D$. An overview of adakite, tonalite Trondhjemite Granodiorite (TTG), and sanukitoid: relationships and some implications for crustal evolution. Lithos. 2005. Vol. 79. P. 1-24.

Meert J. G., Pandit M. K., Pradhan V. R., Kamenov G. Preliminary report on the paleomagnetism of $1.88 \mathrm{Ga}$ dykes from the Bastar and Dharwar cratons, Peninsular India. Gondwana Res. 2011. Vol. 20. P. 335-343.

Mikkola P., Lauri L. S., Käpyaho A. Neoarchean leucogranitoids of the Kianta Complex, Karelian Province, Finland: Source characteristics and processes responsible for the observed heterogeneity. Precambrian Res. 2012. Vol. 206-207. P. 72-86.

Mikkola P., Heilimo E., Halkoaho T., Käpyaho A. The tectonomagmatic significance of Neoarchaean variably alkali-enriched gabbro and diorite intrusions of the western Karelia Province. Halla J., Whitehouse M. J., AhmadT., Bagai Z. (eds), Crust-Mantle Interactions and Granitoid Diversification: Insights from Archaean Cratons. Geol. Society, London. Special Publications, 449. 2017. P. 39-60. doi: 10.1144/ SP449.5

Mikkola P., Heilimo E., Paavola J., Halkoaho T., Äikäs O., Huhma H. Bedrock of the southern part of Lentua complex. Geol. Survey of Finland. Report of Investigation 202. 2013. 123 p. (In Finn.)

Mikkola P., Huhma H., Heilimo E., Whitehouse M. Archean crustal evolution of the Suomussalmi district as part of the Kianta Complex, Karelia: Constraints from geochemistry and isotopes of granitoids. Lithos. 2011. Vol. 125. P. 287-307.

Mints M. V., Belousova E. A., Konilov A. N., Natapov L. M., Shchipansky A. A., Griffin W. L., O'Reilly S. Y., Dokukina K. A., Kaulina T. V. Mesoarchean subduction processes: $2.87 \mathrm{Ga}$ eclogites from the Kola Peninsula, Russia. Geology. 2010. Vol. 38. P. 739-742.

Mints M. V., Dokukina K. A., Konilov A. N., Philippova I. B., Zlobin V. L., Babayants P. S., Belousova E. A., Blokh Y. I., Bogina M. M., Bush W. A., Dokukin P. A.,
Kaulina T. V., Natapov L. M., Piip V. B., Stupak V. M., Suleimanov A. K., Trusov A. A., Van K. V., Zamozhniaya N. G. East European Craton: Early Precambrian history and 3D models of deep crustal structure. The Geol. Society of America Special Paper, 510. 2015. 500 p. doi: 10.1130/2015.2510

Mondal M. E. A., Goswami J. N., Deomurari M. P., Sharma K. K. Ion microprobe $\mathrm{Pb}^{207} / \mathrm{Pb}^{206}$ ages of zircons from the Bundelkhand massif, northern India: implications for crustal evolution of the Bundelkhand-Aravalli protocontinent. Precambrian Res. 2002. Vol. 117. P. 85-100.

Mondal M. E. A., SharmaK.K., Rahman A., Goswami J. N. Ion microprobe $\mathrm{Pb}^{207} / \mathrm{Pb}^{206}$ zircon ages for gneiss-granitoid rocks from Bundelkhand massif: evidence for Archaean components. 1998. Vol. 74 P. 70-75.

Mondal M. E. A. and Raza A. Geochemistry of sanukitoid series granitoids from the Neoarchaean Berach granitoid batholiths, Aravalli craton, northwestern Indian shield. Current Sci. 2013. Vol. 104. P. 102-108.

Moyen J. F. The composite Archaean grey gneisses: petrological significance, and evidence for a non-unique tectonic setting for Archaean crustal growth. Lithos. 2011. Vol. 123. P. 21-36.

Moyen J. F., Martin H., Jayananda M. Multi-element geochemical modelling of crust - mantle interactions during late-Archaean crustal growth: the Closepet granite (South India). Precambrian Res. 2001. Vol. 112. P. 87-105.

Moyen J. F., Martin H., Jayananda M., Auvray B. Late Archaean granites; a typology based on the Dharwar Craton, India. Precambrian Res. 2003. Vol. 127. P. 103-123.

Mutanen T., Huhma H. The $3.5 \mathrm{Ga}$ Siurua trondhjemite gneiss in the Archaean Pudasjärvi Granulite Belt, northern Finland. Bull. Geol. Soc. Finland. 2003. Vol. 75. P. 51-68.

Nagel T. J., Hoffmann J. E., Münker C. Generation of Eoarchean tonalit-trondhjemite-granodiorites series from thickened mafic arc crust. Geology. 2012. Vol. 40. P. 375-378.

Oliveira M. A., Dall'Agnol R., de Arimate'ia Costa de Almeida J. Petrology of the Meso- Archaean Rio Maria suite and the discrimination of sanukitoid series. Lithos. 2011. Vol. 127. P. 192-209.

Ovchinnikova G. V., Matrenichev V. A., Levchenkov O. A., SergeevS. A., Yakovleva S. Z., Gorohovsky $O$. A. U-Pb and $\mathrm{Pb}-\mathrm{Pb}$ isotopic studies of felsic volcanics from the Hautavaara greenstone structure, Central Karelia. Petrology. 1994. Vol. 2(3). P. 266-281. (In Russ.).

Pati J. K., Patel S. C., Pruseth K. L., Malviya V. P., Arima M., Raju S., Pati P., Prakash K. Geology and Geochemistry of giant quartz veins from the Bundelkhand Craton, central India and their implications. J. Earth Syst. Sci. 2007. Vol. 116(6). P. 497-510.

Pati J. K., Raju S., Malviya V. P., Bhushan R., Prakash K., PatelS. C. Mafic dykes of Bundelkhand craton, Central India: Field, Petrological and Geochemical characteristics. Srivastava et al. (eds). Indian dykes: geochemistry, geophysics and geochronology. New Delhi: Narosa Publishing House, 2008. P. 547-569. 
Pati J. K., Raju S., Pruseth K. L., Magngain V. D., Shankar R. Gold mineralization in parts of Bundelkhand Granitoid Complex (BGC). J. Geol. Soc. India. 1997. Vol. 50. P. 601-606.

Patiño Douce A. E., Beard J. S. Dehydration melting of biotite gneiss and quartz amphibolite from 3 to 15 kbar. J. Petrol. 1995. Vol. 36. P. 707-738.

Patiño Douce A. E. Vapor-absent melting of tonalite at 15-32 kbar. J. Petrol. 2005. Vol. 46. P. 275-290.

Polat A., Kerrich R. Nd-isotope systematics of $\sim 2.7 \mathrm{Ga}$ adakites, magnesian andesites, and arc basalts, Superior Province: evidence for shallow crustal recycling at Archean subduction zones. EPSL. 2002. Vol. 202(2). P. 345-360.

Pradhan V. R., $\quad$ Meert J. G., $\quad$ Pandit M. K., Kamenov G., Mondal E. A. Tectonic evolution of the Precambrian Bundelkhand craton, central India: Insights from paleomagnetic and geochronological studies on the mafic dyke swarms. Precambrian Res. 2012. Vol. 198-199. P. 51-76.

Radhakrishna B. P. Suspect Tectono-stratigraphic Terrane elements in the Indian Subcontinent. J. Geol. Soc. India. 1989. Vol. 34. P. 1-24.

Rahman A., Zainuddin S. M. Bundelkhand granites: an example of collision-related Precambrian magmatism and its relevance to the evolution of central Indian shield. J. Geol. 1993. Vol. 101. P. 413-419.

Ramakrishnan M., Vaidyanadhan R. Geology of India. Geol. Society of India, Bangalore. 2010. Vol. 1. $556 \mathrm{p}$.

Ramiz M. M., Mondal M. E. A. Petrogenesis of mafic magmatic enclaves of the Bundelkhand granitoids near Orccha, Central Indian shield: evidence from rapid crystallization. Halla J., Whitehouse M., Ahmad T., Bagai Z. (eds). Crust-Mantle Interactions, Granitoid Diversification: Insights from Archaean Cratons. Geol. Society, London. Special Publications, 449. 2017. P. 159-173. doi: 10.1144/SP449.6

Rao J.M., Rao G. V. S. P., Widdowson M., KelleyS.P. Evolution of Proterozoic mafic dyke swarms of the Bundelkhand Granite Massif, Central India. Current Sci. 2005. Vol. 88. P. 502-506.

Rapp R. P., Watson E. B. Dehydration melting of metabasalt at 8-32 kbar implications for continental growth and crust-mantle recycling. J. Petrol. 1995. Vol. 36. P. 891-931.

Rapp R. P., Watson E. B., Miller C. F. Partial melting of amphibolite eclogite and the origin of Archean trondhjemites and tonalites. Precambrian Res. 1991. Vol. 51. P. 1-25.

Rapp R., Norman M., Laporte D., Yaxley G. M., Martin H., FoleyS. F. Continent formation in the Archean and chemical evolution of the cratonic lithosphere: meltrock reaction experiments at 3-4 GPa and petrogenesis of Archean Mg-diorites (sanukitoids). J. Petrol. 2010. Vol. 51. P. 1237-1266.

Reddy S. M. D., Evans A. D. Palaeoproterozoic supercontinents and global evolution: correlations from core to atmosphere. Geol. Society, London. Special Publications, 323. 2009. P. 1-26. doi: 10.1144/SP323.1

Roday P. P., Diwan P., Singh S. A synkinematic model of emplacement of quartz reefs and subsequent deformation patterns in the central Indian Bundelkhand batholith. Proceed. Indian Acad. of Sci. (Earth and Planetary Sci.). 1995. Vol. 104. P. 465-468.

Saha L., Pant N.C., PatiJ.K., BerndtJ., Upadhyay D., Bhattacharya A., Satynarayanan M. Neoarchaean high-pressure margarite-phengitic muscovitechlorite corona mantled corundum in quartz-free high$\mathrm{Mg}$, Al phlogopite-chlorite schists from the Bundelkhand craton, north central India. Contributions to Mineralogy and Petrology. 2011. Vol. 161. P. 511-530.

Saha L., FreiD., Gerdes A., Pati J.K., Sarkar S., Patole V., Bhandari A., Nasipuri P. Crustal geodynamics from the Archaean Bundelkhand Craton, India: constraints from zircon U-Pb-Hf isotope studies. Geol. Magazine. 2016. Vol. 153. P. 79-192. doi: 10.1017/ S0016756815000692

Samsonov A. V., Larionova Yu. O., Bibikova E. V., Petrova A. Yu., Puchtell. S. Magnesian granitoids (sanukitoids) of the Kostomuksha area, western Karelia: Petrology, geochronology, and tectonic environment of formation. Petrology. 2004. Vol. 12(5). P. 437-468.

Sarkar A., PaulD. K., Potts P. J. Geochronology and geochemistry of the Mid-Archaean trondhjemitic gneisses from the Bundelkhand Craton, Central India. Saha A. K. (eds). Recent Res. in Geol. and Geophysics of the Precambrian. A Series. 1996. P. 76-92.

Sergeev S. A., Larionov A. N., Berezhnaya N. G., Lobach-Zhuchenko S. B., Guseva N. S. Archean Age of Miaskite Lamproits in the Panozero Complex, Karelia. Dokl. Earth Sci. 2007. Vol. 413(3). P. 420-423.

Sharma K. K., Rahman A. The Early Archaean-Paleoproterozoic crustal growth of the Bundelkhand craton, northern Indian shield. M. Deb (eds). Crustal evolution and Metallogeny in the northwestern Indian Shield. New Delhi: Narosa Publishing House, 2000. P. 51-72.

Shchipansky A. A. Subduction geodynamics in $\mathrm{Ar}-$ chean and formation of diamond-bearing lithospheric keels and early continental crust of cratons. Geotectonics. 2012. Vol. 46. P. 122-141. doi: 10.1134/ S0016852112020057

Shirey S. B., Hanson G. N. Mantle-derived Archaean monzodiorites and trachyandesites. Nature. 1984 Vol. 310. P. 222-224

Singh P. K., Verma S. K., Singh V. K., Moreno J. A., Oliveira E. P., Mehta P. Gochemistry and petrogenesis of sanukitoids and high-K anatectic granites from the Bundelkhand Craton, India: Implications for lateArchean crustal evolution. J. Asian Earth Sci. 2018. doi: 10.1016/j.jseaes.2018.12.013

Singh S. P., Bhattacharya A. R. Signature of Archaean E-W crustal-scale shears in the Bundelkhand Massif Central India, an example of vertical ductile shearing. Earth Sci. India. 2010. Vol. 3. P. 217-225.

Singh S. $P$. Geochemical signature of Archean felsic volcanism in central part of Bundelkhand Craton. Int. J. of Advances in Earth Sci. 2012. Vol. 1. P. 20-32.

Singh V. K., SlabunovA. The Greenstone belts of the Bundelkhand craton, Central India: new geochronological data and geodynamic setting. Singh V. K. and Chandra R. (eds). Int. Association for Gondwana Res. conf. Series No. 16. $3^{\text {rd Int. Conf. Precambrian Continental }}$ Growth and Tectonism. Jhansi, India. 2013. P. 170-171.

Singh V. K., Slabunov A. The Central Bundelkhand Archaean greenstone complex, Bundelkhand craton, 
Central India: geology, composition, and geochronology of supracrustal rocks. Int. Geol. Rev. 2015. Vol. 57. P. 1349-1364.

Singh V. K., Slabunov A. Two types of Archaean supracrustal belts in the Bundelkhand Craton, India: geology, geochemistry, age and implication for craton crustal evolution. J. Geol. Soc. India. 2016. Vol. 88. P. 539-548.

Skjerlie K. P., Johnston A. D. Fluid-Absent Melting Behavior of an F-Rich Tonalitic Gneiss at Mid-Crustal Pressures: Implications for the Generation of Anorogenic Granites. J. Petrol. 1993. Vol. 34. P. 785-815.

Slabunov A. I. Geology and geodynamics of Archean mobile belts (example from the Belomorian province of the Fennoscandian Shield). Petrozavodsk: KarRC RAS, 2008. 298 p. (In Russ.).

Slabunov A. I., Azimov P. Ya., Glebovitsky V. A., Zhang L., Kevlich V. I. Archean and Paleoproterozoic migmatization in the Belomorian Province, Fennoscandian Shield: petrology, geochronology and geodynamic setting. Dokl. Earth Sci. 2016. Vol. 467(1). P. 71-74.

Slabunov A., Egorova S., Singh V. K., Svetov S., Kumar $S$. Archean mafic-ultramafic Ikauna layered intrusion, Bundelkhand craton, India: petrography and geochemistry. Arch \& Anthropol. Open Acc.3 (suppl-2). 2018a. P. 49-55. doi: 10.31031/AAOA. 2018.03.000557

Slabunov A. I., HölttäP., Sharov N. V., Nesterova N. S. A 4-D framework of the Fennoscandian Shield earth Crust growth in Archean: synthesis of off-theshelf geological data. Geol. of Karelia from the Archaean to the present: Proceed. All-Russ. conf. dedicated the $50^{\text {th }}$ anniv. of the Inst. of Geol. foundation. May 24-26. Petrozavodsk: KarRC RAS, 2011a. P. 13-21.

SlabunovA., KulikovV., Kulikova V., SibelevO. Neoarchean granulite and Paleoproterozoic dykes of the Vodlozero subprovince, Karelian Craton. Rodinia-2013: Supercontinental Cycles and Geodynamics (Early Precambrian of Russian Karelia). Petrozavodsk; Moscow, 2013. P. 22-41.

Slabunov A. I., Lobach-Zhuchenko S. B., Bibikova E. V., BalaganskyV. V., Sorjonen-WardP., VolodichevO. I., ShchipanskyA.A., SvetovS. A., Chekulaev V. P., Arestova N. A., Stepanov V. S. The Archaean of the Baltic Shield: geology, geochronology, and geodynamic settings. Geotectonics. 2006a. Vol. 40(6). P. 409-433. doi: 10.1134/s001685210606001x

Slabunov A. I., Lobach-Zhuchenko S. B., Bibikova E. V., Sorionen-WardP., BalaganskyV. V., VolodichevO. I., ShchipanskyA.A., SvetovS. A., Chekulaev V. P., Arestova N. A, Stepanov V. S. The Archean nucleus of the Fennoscandian (Baltic) Shield. Gee D. G., Stephenson R. A. (eds). European Lithosphere Dynamics. Geol. Society, London. Memoirs, 32. 2006b. P. 627-644.

Slabunov A. I., Singh V. K. Archaean crustal evolution of the Fennoscandian and Bundelkhand craton: prospective. Singh V. K. and Ram Chandra (eds). Precambrian Continental Growth and Tectonism. Proceed. $2^{\text {nd }}$ Int. conf. 2011b. P. 3-12.

Slabunov A. I., Singh V. K. Meso-Neoarchean crustal evolution of the Bundelkhand Craton, Indian Shield: new data from greenstone belts. Int. Geol. Review. 2018b. doi: 10.1080/00206814.2018.1512906

Slabunov A. I., Singh B. U-Pb geochronology of zircons from the banded iron formation of the Bundelkhand
Craton, India: constraints for the timing of formation. Methods and geological results of the study of isotopic geochronometric mineral and rock systems. $7^{\text {th }}$ Russian conference on isotope geochronology. Moscow: IGEM RAS, 2018c. P. 331-334.

Slabunov A. I., Singh V., Joshi K. B., LiX. Paleoarchean zircons from quartzite of South Bundelkhand Supracrustal Complex: origin and implications for crusta evolution in Bundelkhand Craton, Central India. Current Sci. 2017a. Vol. 112(4). P. 794-801.

Slabunov A. I., SinghV. K., ShchiptsovV. V., Lepekhina E. N., Kevlich V. I. A new Paleoproterozoic $(1.9-1.8 \mathrm{Ga})$ event in the crustal evolution of the Bundelkhand Craton, India: the results of (SHRIMP) Dating of zircons from giant quartz veins. Slabunov A. I., Svetov S. A., Baltibaev Sh. K. (eds). Early Precambrian vs Modern Geodynamics. Petrozavodsk: KarRC RAS, 2017b. P. 239-241.

SlabunovA. I., VolodichevO. I., KorolN. E., Sibelev O. S., Berezhnaya N. G., Larionov A. N. Archean granulites of Karelian Craton: petrology, geochronology, geodynamics. Proceed. XII All-Russ. petrographic conf. Petrozavodsk: KarRC RAS, 2015. P. 503-506. (In Russ.).

Smithies R. H., Champion D. C. The Archaean high$\mathrm{Mg}$ diorite suite: Links to tonalite-trondhjemite-granodiorite magmatism and implications for early Archaean crustal growth. J. Petrol. 2000. Vol. 41. P. 1653-1671.

Smithies R. H., Champion D. C. Archaean high-Mg diorites (sanukitoid) suite, Pilbara Craton, Western Australia. B. Barbarin (ed). The Origin of granites and related rocks: Fourth Hutton Symposium Abs., September 1999. Clermont Ferrand, France. 190 p.

Smithies R. H., Champion D. C., van Kranendonk M.J. Formation of Palaeoarchean crust through infracrustal melting of enriched basalt. EPSL. 2009. Vol. 281. P. 298-306.

Sorjonen-Ward $P$. An overview of structural evolution and lithic units within and intruding the late Archean Hattu schist belt Ilomantsi eastern Finland. Geol. Survey of Finland. Special Paper, 17. 1993. P. 9-102.

Sorjonen-Ward P., Claoué-Long J. Preliminary note on ion probe results for zircons from the Silvevaara granodiorite, Ilomantsi, Eastern Finland. Autio S. (ed.). Geol. Survey of Finland, Current Res. 1991-1992, Geol. Survey of Finland, Special Paper, 18. 1993. P. 25-29.

Sorjonen-Ward P., Luukkonen E. Archean rocks. Lehtinen M., Nurmi P. A., RämöO. T. (eds), The Precambrian Geology of Finland - key to the evolution of the Fennoscandian Shield. Amsterdam: Elsevier, 2005. P. 19-99.

Stein H. J., Hannah J. L., Zimmerman A., MarkeyR. J., Sarkar S. C., Pal A. B. A 2.5 ga porphyry cumo-au deposit at Malanjkhand, central India; implications for late Archean continental assembly. Precambrian Res. 2004. Vol. 134. P. 189-226.

Stern R. A. Petrogenesis of Archaean sanukitoid suite: PhD thesis, State University of New York at Stony Brook, 1989. $275 \mathrm{p}$.

Stern R. A., Hanson G. N. Archean high-Mg granodiorites: a derivative of light rare earth enriched monzodiorite of mantle origin. J. Petrol. 1991. Vol. 32. P. 201-238.

Stevenson R., Henry P., Gariépy C. Assimilationfractional crystallization origin of Archaean sanukitoid 
suites: Western Superior Province, Canada. Precambrian Res. 1999. Vol. 96. P. 83-99.

Sun S. S., McDonough W. F. Chemical and isotopic systematics of oceanic basalts: implications for mantle composition and processes. Geol. Society, London. Special Publications, 42. 1989. P. 313-345.

Svetov S. A. The oldest adakites of the Fennoscandian Shield. Petrozavodsk: KarRC RAS, 2009. 115 p. (In Russ.).

Svetov S. A., Svetova A. I., Nazarova A. I. VedlozeroSegozero greenstone belt, Central Karelia: new geochronological data and interpretation of results. Geol. and useful minerals of Karelia. 2010. Vol. 13. P. 5-12. (In Russ.).

Sylvester P. J. Archaean granite plutons. Condie C. (ed.) Archaean Crustal Evolution. Amsterdam: Elsevier, 1994. P. 261-314.

van Hunen J., van den Berg A. P. Plate tectonics on the early Earth: imposed by strength and buoyancy of subducted lithosphere. Lithos. 2008. Vol. 103. P. 217-235.

Vaasjoki M., Sorjonen-Ward P., Lavikainen S. U-Pb age detrminations and sulfide $\mathrm{Pb}-\mathrm{Pb}$ characteristic from the late Archean Hattu Schist belt, llomantsi, eastern Finland. Nurmi P. A., Sorjonen-Ward P. (eds.). Geol. development, gold mineralization and exploration methods in the late Archean Hattu schist belt, llomantsi, eastern
Finland: Geol. Survey of Finland, Special Paper, 4. 1993. P. 103-132.

Verma S. K., Verma S. P., Oliveira E. P., Singh V. K., More J. A. LA-SF-ICP-MS zircon U-Pb geochronology of granitic rocks from the central Bundelkhand greenstone complex, Bundelkhand craton, India. J. Asian Earth Sci. 2016. Vol. 118. P. 125-137.

VolodichevO. I., SlabunovA. I., KuzenkoT. I., Bibikova E. V., Konilov A. N. Archean eclogites in the Belomorian mobile belt, Baltic shield. Petrology. 2004 Vol. 12(6). P. 540-560.

Watkins J. M., Clemens J. D., Treloar P. J. Archaean TTGs as sources of younger granitic magmas: melting of sodic metatonalites at 0.6-1.2 GPa. Contributions to Mineralogy and Petrology. 2007. Vol. 154. P. 91-110.

Willbold M., Hegner E., Stracke A., Rocholl A. Continental geochemical signature in dacites from Iceland and implications of early Archaean crust formation. EPSL. 2009. Vol. 279. P. 44-52.

Zhitnikova I. A., Miskova T. A., PresnyakovS. L., L'vov $P$. A. Isotopic age and composition of Mesoarchean mafic magmatism in South-Vigozero greenstone belt. Proceed. All-Russ. conf. dedicated to $150^{\text {th }}$ anniv. of academician F. Levinson-Lessing and $100^{\text {th }}$ of professor G. Saranchina. St. Petersburg, 2012. Vol. 1. P. 213-215. (In Russ.).

Received April 13, 2018

\section{СВЕДЕНИЯ ОБ АВТОРАХ:}

\section{Джоши Кумар Батук}

научный сотрудник, к. г.-м. н. (PhD)

Лаборатория физических исследований

Ахмедабад, Гуджарат, Индия

Национальный исследовательский центр наук о Земле

Министерства землеведения Индии

Тривандрам, Керала, Индия

эл. почта: kr.batukjoshi@gmail.com

\section{Слабунов Александр Иванович}

заведующий лаб. геологии и геодинамики докембрия,

д. г.-М. н., проф.

Институт геологии КарНЦ РАН,

Федеральный исследовательский центр

«Карельский научный центр РАН»

ул. Пушкинская, 11, Петрозаводск, Республика Карелия,

Россия, 185910

эл. почта: slabunov@krc.karelia.ru

\section{CONTRIBUTORS:}

Joshi, Kumar Batuk

Physical Research Laboratory

Ahmedabad, Gujrat, India

ESSO-National Centre for Earth Science Studies Ministry of Earth Sciences, Government of India

Thiruvananthapuram, Kerala, India

e-mail: kr.batukjoshi@gmail.com

Slabunov, Alexander

Institute of Geology, Karelian Research Centre,

Russian Academy of Sciences

11 Pushkinskaya St., 185910 Petrozavodsk, Karelia, Russia

e-mail: slabunov@krc.karelia.ru 